\title{
Stress and well-being at work: A century of empirical trends reflecting theoretical and societal influences.
}

DOI:

10.1037/apl0000109

Document Version

Accepted author manuscript

Link to publication record in Manchester Research Explorer

\section{Citation for published version (APA):}

Bliese, P., Edwards, J., \& Sonnentag, S. (2017). Stress and well-being at work: A century of empirical trends reflecting theoretical and societal influences. Journal of Applied Psychology. https://doi.org/10.1037/apl0000109

\section{Published in:}

Journal of Applied Psychology

\section{Citing this paper}

Please note that where the full-text provided on Manchester Research Explorer is the Author Accepted Manuscript or Proof version this may differ from the final Published version. If citing, it is advised that you check and use the publisher's definitive version.

\section{General rights}

Copyright and moral rights for the publications made accessible in the Research Explorer are retained by the authors and/or other copyright owners and it is a condition of accessing publications that users recognise and abide by the legal requirements associated with these rights.

\section{Takedown policy}

If you believe that this document breaches copyright please refer to the University of Manchester's Takedown Procedures [http://man.ac.uk/04Y6Bo] or contact uml.scholarlycommunications@manchester.ac.uk providing relevant details, so we can investigate your claim.

\section{OPEN ACCESS}


Stress and Well-Being at Work:

A Century of Empirical Trends Reflecting Theoretical and Societal Influences

\author{
Paul Bliese \\ Jeff Edwards
}

Sabine Sonnentag 


\begin{abstract}
In one form or another, research on stress and well-being has been a part of JAP since its inception. In this review, we examine the history of stress research in JAP by tracking word frequencies from 606 abstracts of published articles in the journal. From these abstracts, we define three eras: a 50 year-era from 1917 to1966, a 30-year era from 1967 to 1996, and a 20year era from 1997 to the present. Each era is distinct in terms of the number of articles published and the specific topics examined. We show that advances in theory are a major impetus underlying the topics examined and the number of publications. We also show that articles have increasingly tended to reflect broader events occurring in society such as recessions and work-force changes. We conclude by offering ideas about the future of stress and well-being research.
\end{abstract}


April 6, 1917: the US enters the Great War - a war that requires another war before earning the name "World War I". Roughly one year later, an influenza epidemic kills over 500,000 US citizens. In the following year, the nation's concerns about alcohol abuse lead to a 14 year period of prohibition. Twelve years after 1917, the stock market crash of 1929 culminates in the great depression and tens of thousands remain unemployed for years.

By most objective standards, the decades following the inception of the Journal of Applied Psychology (JAP) were a remarkably stressful period for workers (and citizens) in the US and much of the world. With these events as backdrop, one would expect to find that the topic of stress dominated the early pages of JAP. Perhaps not surprisingly, the story is more complicated: the journal does indeed reflect the influence of stressors occurring within society, but research on stress and well-being in work contexts was relatively rare for approximately the first 50 years although traces of what we now view as stress research can be seen as early as 1917.

For instance, Fish (1917) discussed the challenges of maintaining a skilled workforce "as the country is drawn into war" (p. 161) and raises era-relevant concerns about alcohol by stating that "[i]t goes without saying in these days that no employer wishes to have any of his men under the influence of liquor... because we all realize now that a man is stupefied to some extent even by what is known as moderate drinking" (p. 165). Fish goes on to write that the "first essential" for meeting labor demands is that the "shop shall be comfortable in both a physical and a mental way" (p. 162). Fish's interests in stress and well-being were not unique and were mirrored in the broad "mental hygiene" movement of the time (e.g., Martin, 1917). Martin advocated a broad agenda, arguing that " $[\mathrm{b}] \mathrm{y}$ mental hygiene I mean the psychological work to be done in creating, maintaining and restoring normal mental activity in a given individual. There are many reasons 
why our association should immediately take the lead, set the pace as it were, in this matter of mental hygiene" (p. 67).

A final example of the traces of what we recognize as stress research is reflected in Hall's (1917) description of soldiers' stress reactions to the demands of war. Hall wrote "We shall surely have a new and larger psychology of war. The older literature on it is already more or less obsolete from almost every point of view, and James' theory of a moral, and Cannon's of a physiological, equivalent of war seem now pallid and academic" (p. 12).

Although there was clearly an early impetus to focus on factors related to stress and wellbeing, the research evidence suggests the agenda was not widely adopted in the early years of $J A P$. Furthermore, published articles during the early decades failed to reflect the broad visions proposed by individuals such as Hall, Martin, and Fish. Instead, articles we recognize as stress research tended to examine demographic variables such as age, race, profession, and physical activity as predictors of outcomes such as mental fatigue and psychoneurotic traits (e.g., Garth, 1920; Elwood, 1927). While these types of articles laid the foundations for future work, they did not really capture the calls to "immediately take the lead" with respect to "maintaining and restoring" mental hygiene by Martin or in meeting the "first essential" for "comfortable" shops advocated by Fish or in advancing a "new and larger psychology of war" anticipated by Hall.

Based on our review, it took 16 years for the journal to publish a study that can be clearly identified as having both a work-relevant stressor and strain. Laird (1933) experimentally examined the effects of loud noise (an organizational stressor) and noted that loud noise appeared to cause somatic complaints (a strain). Laird wrote that "[w]ith the more intense noises muscular stiffness was noted, especially in the neck and legs" (p. 328) and goes on to speculate that the stiffness was due to an accumulation of lactates given that "[n]either of these groups of 
muscles was used during the work period..." (p. 328). Laird's examination of work stressors and strains associated with the industrial age was followed by others, but the number of publications was relatively rare for another 30 or so years at which point (the mid to late 1960s) the rate of publications increased substantially. ${ }^{1}$

In this review, we follow the development of stress and well-being research published in $J A P$ over the past 100 years. We examine how publication trends were influenced by larger societal events and developments in stress theory. The foundation of our review is based upon 606 stress-related articles published in the Journal from 1917 to present.

The specific structure of our manuscript is as follows: First, we begin by defining key terms. Second, we examine significant historic events and macro societal trends that frame stress research. Third, we identify key developments in theory related to stress and well-being. Fourth, we examine articles published within the journal over the past 100 years and consider how these publications relate to events within society and to advances in theory. As part of our review, we identify articles that we consider exemplary and influential. Finally, we summarize the first century; take stock of theoretical and empirical research, and discuss future directions.

\section{Defining Key Terms}

When summarizing theory and empirical research on stress and well-being, one of the key challenges involves the ambiguity of key terms. The term "stress", in particular, is conceptually ambiguous because it can refer to an event causing a subsequent reaction, the person's reaction to the event, or the relationship between the person and situation (Hobfoll, 1989; Jex, Beehr, \& Roberts, 1992; McGrath, 1970). For this reason, stress research often

\footnotetext{
${ }^{1}$ As a point of interest, we note that Laird is one of the top 25 stress-related articles for citation rates in the first 50 years of the journal (see online Appendix B).
} 
differentiates stressors (events causing subsequent reactions), perceived stress (perception and appraisal of the stressors), and strains (physiological, emotional, or performance effects).

As we note in the review, research in the domain of stress and well-being has also focused heavily on moderators, such as attributes of the individual or work environment that alter the strength of links between stressors, perceived stress, and strains. In this review, we differentiate among stressors, perceived stress, strain, and moderators. We reserve the term "stress" to designate the domain of stress research (cf. Kahn \& Byosiere, 1992).

\section{Historic Events and Macro Societal Trends}

Scientific journals vary in the degree to which published articles are expected to mirror broad societal events. However, it is reasonable to assume that, as an applied journal, JAP would publish articles that reflect societal events. Based on this assumption, we assembled a chronology of significant events in the US that would ostensibly have signified stressors and engendered strain in the working population. Online Appendix A lists these events, and we supplement these events by identifying systemic changes in society that span the time frame of our review.

\section{Macro Societal Trends}

As a whole, the century between 1917 and 2017 represented a period of major political, economic, technological, and societal change. Major historic events include two World Wars and other major wars (e.g., Korean War, Vietnam War). The century also witnessed the emergence of new nations, mainly in Africa and Asia, along with the rise and fall of the Soviet Union. People faced times of economic turbulences. The Great Depression (1929-1939) had a major impact on many countries to include the US where the gross national product dropped substantially and unemployment rates exceeded 20 percent. 
Technology also transformed how people lived and worked. In the early $20^{\text {th }}$ century, industrial work was dominated by mass production, enabled by the assembly line popularized within the Ford Motor Company in 1913. During the subsequent decades, rationalization of tasks and jobs continued (Davis \& Taylor, 1972). These developments triggered employee reactions such as alienation invoking feelings of powerlessness, meaninglessness, social isolation, and self-estrangement (Shepard, 1977). Signs of these effects include large-scale strikes in 1946 and the seizure of US steel mills to avoid strikes in 1952 (online Appendix A).

Throughout the century, information and communication technology influenced all areas of the economy. The introduction of mainframe computers in the 1960s had relatively limited effects, but the subsequent development of microprocessors led to pervasive changes. For instance, the manufacturing industry witnessed the introduction of computer-aided design, computerized machine tools, and industrial robots. Administrative jobs substantially changed with the advent of personal computers following the release of the IBM PC in 1981. The use of computerized communication technologies accelerated after commercial Internet providers increasingly entered the market in the late 1980s as documented by the increase in internet users worldwide from 394 million in 2000 to 2.94 billion in 2014 (Statista, 2015).

With these technological changes, many jobs were no longer restricted to one location (i.e., the traditional office) and could instead be conducted in other places, such as home. On the one hand, this trend contributed to telecommuting arrangements that had the potential to increase individual autonomy and to reduce work-family conflict and role stress (Gajendran \& Harrison, 2007). On the other hand, mobile devices enabled employees in many jobs to work "anywhere, anytime" and stay electronically connected to work outside formal working hours. These changes in work patterns created a situation in which the boundaries between work and life 
became permeable, a development with both positive and negative implications for stress experiences.

Several other major changes occurred during the 20th century. First, jobs in the primary and secondary economic sectors steadily declined, while jobs in the tertiary economic sector increased, particularly in the Western world. For instance, in the US the percentage of employees working in the service sector increased from around $65 \%$ in 1961 to over $85 \%$ in 2010 . This shift reflected a decline of the manufacturing industry and led to changes in job requirements and job stressors, such as reduced physical and environmental stressors (e.g., Laird, 1933) and increased stressors related to emotional labor (Pugliesi, 1999).

Second, the participation of women in the labor market grew dramatically. In 1920, about $20 \%$ of the female US population was employed. This figure rose to $60 \%$ in 2000 , with the largest increase occurring between 1960 and 1980. As a result, men and women living in dualearner families had to deal with changes in work and non-work roles and responsibilities, leading to increases in conflict between work and family (e.g., Higgins, Duxbury, \& Irving, 1992).

Third, during the second half of the 20th century, the economy became increasingly global. This development was accompanied by global competition that may have contributed to an increase in specific stressors, such as increased workload, high job insecurity, and downsizing. Globalization was also associated with increased global mobility of individuals, often leading to stressful experiences for those who had to adjust to a new culture and work environment (Silbiger \& Pines, 2014).

Taken together, these political, economic, technological, and societal developments had broad and significant effects on people's lives, and these events provide a backdrop against which theoretical and empirical research on work-related stress grew and developed. In the next 
section, we summarize significant developments in stress theories during the past century.

\section{Key Theoretical Models}

\section{General Theories of Psychological Stress}

The founding of JAP in 1917 roughly coincided with the beginnings of theory development in contemporary stress research. Most of these early developments originated outside of the organizational literature but were eventually integrated into research on stress in work settings. In this section, we first summarize key theoretical models in the literature on psychological stress in general and then turn to models devoted to stress in work settings.

Historical accounts of the stress field (e.g., Cooper \& Dewe, 2004; Lazarus, 1993; Mason, 1975a,b) often trace the origins of stress research to Cannon (1915), who coined the phrase "fight or flight" to describe an organism's response to an external threat. Cannon (1932) later indicated that the response to threat represents deviation from homeostasis, which he viewed as the self-regulation of physiological processes. A subsequent landmark in stress research is the work of Selye (1936), who described reactions to stress in terms of the General Adaptation Syndrome (GAS), which referred to the nonspecific response of the body to any demand. According to Selye, the GAS comprised three stages that included alarm, resistance, and exhaustion, the first two of which involved attempts to adapt to the demand, and the third indicating depletion of adaptive energy. Like Cannon, Selye focused on physiological responses to stress, such as changes in adrenaline, cortisol, and other hormones.

The field of stress research experienced a noticeable shift following the 1950s when it began to focus on major life events that required adjustment and led to psychological and physical illness (Dohrenwend \& Dohrenwend, 1981; Thoits, 1983). This research was stimulated by the development of the Social Readjustment Rating Scale (SRRS; Holmes \& Rahe, 
1967), a checklist that comprised 43 stressful life events. Scores on the SRRS were weighted by the amount of readjustment each event was deemed to require and summed to derive an overall measure of life stress. The SRRS has been used in numerous studies (Dohrenwend, 2006), although its relationships with mental and physical symptoms were generally modest, with correlations rarely exceeding .30 .

The modest relationships between life events and illness prompted investigations into factors that might moderate these relationships, such as personality, self-esteem, social support, and the meaning of the event to the individual (Cohen \& Edwards, 1989; Cohen \& Wills, 1985; Kessler, Price, \& Wortman, 1985). This line of research showed that the relationship between life events and outcomes depended on event timing and magnitude as well as the undesirability and control over the events as perceived by the individual (Mullen \& Suls, 1982; Thoits, 1983; Vinokur \& Selzer, 1975). As such, this research began to underscore the essential role of individual differences in the stress process, a theme that permeated subsequent theoretical work.

Arguably, one of the most influential theoretical models of psychological stress was the transactional theory presented by Lazarus in 1966 and later expanded by Lazarus and Folkman in 1984. Lazarus' theory reinforced the importance of subjective factors in the stress process and asserted that the effects of potential stressors on well-being were largely determined by how they were cognitively appraised by the individual. Lazarus distinguished two forms of cognitive appraisal: (a) primary appraisal, which determined whether a potential stressor was viewed as harmful, threatening, or challenging; and (b) secondary appraisal, which considered what individuals might do to manage the stressful transaction. Lazarus' work also placed particular emphasis on the ways in which individuals cope with stress (e.g., Lazarus, 1993; Lazarus, Averill, \& Opton, 1974). Lazarus contrasted coping styles, which are individual differences that 
characterize how people cope, with coping processes, which concerns the particular approaches people use to manage stressful transactions between the person and situation. This work stimulated the development of measures designed to assess the variety of processes by which people cope with stress, of which the Ways of Coping Questionnaire (Folkman \& Lazarus, 1988) became the most widely used.

The central importance of cognitive appraisal underscored by Lazarus was maintained in subsequent theoretical work. A prime example is the conservation of resources (COR) theory proposed by Hobfoll (1989). This theory posits that stress occurs when resources the individual considers valuable are threatened, lost, or foregone. Resources in COR theory refer to objects, conditions, and personal characteristics that are valued in their own right or because they can help the individual achieve or protect other valued resources. COR theory was initially framed as an alternative to appraisal-based theories, such as Lazarus' transactional theory, by placing greater emphasis on the objective environment as a determinant of stress. Nonetheless, cognitive appraisal plays a key role in the evaluation of resources, the perception that resources are at risk, and other basic processes involved in COR theory.

\section{Theories of Stress in Work Contexts}

Many of the theoretical developments in research on psychological stress have parallels in theories that focus on stress in the workplace. For example, Bhagat (1983) proposed a model of the effects of stressful life events on individual performance, satisfaction, and adjustment in organizational settings and developed a checklist that distinguished potentially stressful events associated with job and personal domains (Bhagat, McQuaid, Lindholm, \& Segovis, 1985). Other frameworks have focused on work stressors that represent ongoing conditions rather than acute life events. For instance, the review of job stress research by Cooper and Marshall (1976) 
as well as the review by Beehr and Newman (1978) were seminal publications presenting frameworks that identified various job characteristics considered sources of stress. These frameworks also include individual differences that can modify the effects of job stressors, many of which overlap with those examined in psychological stress research. In a similar vein, Karasek (1979) developed a model that focused on two key job characteristics, job demands and job decision latitude, predicting that mental strain is the product of high demands coupled with low decision latitude. Analogously, the challenge-hindrance approach to job stress (Cavanaugh, Boswell, Roehling, \& Boudreau, 2000; LePine, LePine, \& Jackson, 2004) classifies work-related demands and circumstances as challenges or hindrances based on whether they bring about gains or losses for the employee.

Other theories of stress at work emphasize the role of cognitive appraisal, echoing the theories of psychological stress set forth by Lazarus, Hobfoll, and others. A notable example is the theory of role stress by Kahn and colleagues (Kahn \& Quinn, 1970; Kahn, Wolfe, Quinn, Snoek, \& Rosenthal, 1964), which examines how characteristics of organizational roles (e.g., conflict, ambiguity, overload) are perceived and experienced as stressors by role incumbents, leading to affective and physiological symptoms as well as coping responses. Likewise, the person-environment (P-E) fit theory of job stress (French, Caplan, \& Van Harrison, 1982) distinguishes objective person and environment factors from their subjective counterparts and emphasizes that the fit between the subjective person and environment is the key determinant of psychological, physiological, and behavioral strains along with coping and defense mechanisms. Similarly, the cybernetic theories of work-related stress proposed by Cummings and Cooper (1979) and Edwards (1992) frame stress as a discrepancy between perceptions and desires that is considered important by the individual, which lead to psychological and physical symptoms and 
efforts to resolve perceived discrepancies. Along similar lines, the conceptualization of stress in organizations presented by Schuler (1980) posits that stress exists when a person is confronted with demand, constraint, or opportunity for being, having, or doing what he or she desires, which

leads to psychological, physical, and behavioral symptoms as well as efforts to reduce stress and its deleterious effects.

As noted above, theories of work stress that emphasize cognitive appraisal often posit that stress not only influences strains and illness but also triggers coping efforts directed at the sources of stress. Strategies for coping with work-related stress have been discussed (e.g., Dewe, O’Driscoll, \& Cooper, 2010; Latack \& Havlovic, 1992), and some discussions focus on coping with specific sources of stress, such as job loss (Latack, Kinicki, \& Prussia, 1995) and workfamily conflict (Wiersma, 1994). Although coping with work stress has been addressed from a theoretical standpoint, relatively few studies of work stress have examined how people cope with stress. However, studies often include moderator variables as proxies for coping. These variables include individual differences such as personality (Parkes, 1994), locus of control (Marino \& White, 1985), and self-esteem (Ganster \& Schaubroeck, 1991) as well as contextual variables, particularly social support (House, 1981; Viswesvaran, Sanchez, \& Fisher, 1999). In the pages that follow, we use this summary of stress theories as a backdrop against which to review stress research that has appeared in $J A P$. Our review also takes into account the chronology of historical events that have implications for work stress, as presented in the preceding section.

\section{Empirical Word Counts}

The key component of our examination of macro trends over time are $606 \mathrm{JAP}$ articles identified using an "OR" operator on the search terms "stressor," "stress," "strain," "well-being," 
"mental health," "physical health," "illness," "fatigue," "mental hygiene," "anxiety," and "depression." The abstracts from the 606 articles were subjected to word-court frequency using the tm package for R (Feinerer, Hornik \& Meyer, 2008, R Core Team, 2014). While the search terms identify the broader class of relevant literature, the word-count frequencies from abstracts provide insight into the specific research contexts. In this way, the work-count frequencies help capture societal, theoretical, and empirical trends in stress research across the 100 years of our review.

Our goal was to cast a broad net capturing commentary, book reviews, and empirical studies related to stress and well-being. The specific search terms were selected based on (a) an article-by-article examination of the first 10 years of published articles; (b) an examination of articles every fifth year through the 1960s, and (c) our knowledge of terms used in influential books and articles. The article-by-article examination of early editions was critical because terms such as "mental hygiene" and "mental fatigue" are currently uncommon.

The original query returned 642 matches. The early decades had a clear trend in how false positives were generated in that abstracts used the word "stress" as a synonym for "emphasize" as in "the authors stress" in book reviews, so we eliminated 36 articles for this reason. In the early decades, we also excluded several articles that clearly met our search terms in ways we did not intend (e.g., "eyestrain," "judgmental fatigue"). We retained the remaining 606 articles, which provided a rich source for our textual analyses and produced word frequency data consistent with other sources of information, such as citation rates, historic reviews, and our knowledge of the field.

\section{Number of Publications by Year}

Figure 1 provides a visual representation of the annual percent of articles meeting our 
search criteria relative to the total number of publications during the year. Until the 1970s, approximately five percent of the articles met our criteria, with fluctuations between zero and ten percent. Beginning in the late 1960s and early 1970s, between five and ten percent of the articles were focused on stress and well-being, and during the past 15 years over ten percent of the articles in any given year have routinely been focused on stress and well-being. The pattern suggests three broad eras: the 50-year period between 1917 and $1966(\mathrm{n}=173)$; a 30-year period between 1967 and $1996(\mathrm{n}=213)$, and the 20-year period for 1997 to present $(\mathrm{n}=220)$.

The boundaries of these three eras are somewhat arbitrary but correspond with noteworthy landmarks in stress research. For instance, the boundary between the first and second eras roughly coincides with the publication of Kahn et al.'s seminal book on role stress (1964); Kornhauser's book on mental health of the industrial worker (1965), and Lazarus' book on psychological stress and the coping process (1966). The boundary between the second and third eras marks a widespread increase in research related to job stress and health. For instance, in 1986 the WHO Ottawa Charter for Health Promotion was adopted. The Charter emphasized the importance of health and was followed by a partnership between the American Psychological Association (APA) and the National Institute for Occupational Health and Safety (NIOSH) aimed at promoting the new field of occupational health psychology. In addition, in 1996 the first volume of the Journal of Occupational Health Psychology was published, suggesting that the increased interest in job stress research was sufficient to support a new journal.

Figure 2 presents a visual representation of wordclouds for each era. In the wordclouds, a word is presented only if it occurred with at least a frequency of $25 \%$ relative to the total number of articles. With this approach, wordclouds for eras are roughly normalized for differences in the total number of articles. In the wordclouds, the most frequently used words are 
in the center of the cloud, and words further out have lower frequency. Due to the $25 \%$ selection criteria, low frequency words do not appear at all.

Figure 2 conveys the degree to which terminology in $J A P$ articles has consolidated over the years. The relative absence of words in the first era captures the lack of a unifying theoretical framework and the wide diversity of research topics. As such, only 10 words appeared 43 times ( $25 \%$ of 173 ). In contrast, the wordcloud for the second era reveals 24 words that occurred at least 53 times ( $25 \%$ of 213 ), and for the third era, the wordcloud reflects 49 words occurring in at least 55 times (25\% of 220$)$. In the following section, we examine wordcount frequency of the top 25 words by era (see Table 1) and relate these counts to key historic events and major theoretical developments (online Appendices B, C and D provide citations and abstracts for the top 25 most cited articles by era as defined by Google Scholar). We emphasize that we use the words from the abstracts as a foundation of our review, but we readily augment the word frequency data with other data to include citation rates and our knowledge of the field.

\section{The 1917 to 1966 Era}

Perhaps not surprisingly based on the review of key theoretical models, the first era is difficult to characterize from a theoretical perspective. The word frequency for this era (Table 1) reveals that the most frequently used term was the word "book," followed by the words "review(s)" and "author(s)." A large number of articles that met our search criteria during the period were book reviews of books on "mental hygiene" and similar topics related to stress.

While book reviews dominated the first era, traces of what we currently recognize as research on stress and well-being are also evident in the word counts. For instance, a sizeable number of articles published focused on the development and/or use of scales to assess attributes related to stress and well-being. This trend is evident in words such as "scale(s)," "test(s)," 
"study," and "personality" as in "personality tests" along with the words "group(s)," "results," and "difference(s)" reflecting analyses of experimental and descriptive studies often focused on scales and tests (e.g., the "Colgate mental hygiene test" or the "Thorndike addition sheets"). In addition, a large number of the studies focused on students and children (i.e., "child(ren)," "students," "college"). Concerns about "mental hygiene" and "mental health" for children and students were common in the early decades of the journal, but later these topics shifted to other specialized journals. In contrast, words related to "problems", "performance", and "work" would remain central to $J A P$ and the study of stress.

The Great Depression. As noted, the period between 1929 and 1939 represented the Great Depression. A frequency count during this era (43 publications) is largely indistinguishable from the count for the broader era in that key terms remained centered on book reviews and mental hygiene of children. Interestingly, a detailed search for terms specifically related to the economic conditions such as "unemployment" reveals little to suggest that articles in $J A P$ considered these issues relevant, at least from the perspective of stress research.

The Wars. An examination of the 64 publications during the war years (and five-years post-war) reveals that the word "war" appears eight times and words such as "soldier", "officer", and "veteran" do not occur or occur less than two times. The majority of publications related to the war were book reviews ("Shell shock and its aftermath" following WWI, and "The War and Mental Health in England" following WWII). The first research-based publication appears following WWII in a study of attrition from Officer Candidate School (OCS). In this study, Taubman (1947) described a leadership training system designed to work in part by "provid[ing] an atmosphere freed from the tensions and anxieties of OCS". A second article by Anderson (1949) examined a vocational training program for the placement of veterans and focused on 
whether those going through the program had found the training displayed greater "emotional adjustment". It is interesting that, despite the recognition that the wars presented unique opportunities to study stress (e.g., Hall, 1917), there were relatively few empirical studies that focused on stress associated with the wars.

Mass production. Links between the wide-scale adoption of mass production and work stress are reflected in early writings by Fish (1917) and Martin (1917), and words used during this era reflect the industrial age. For instance, the word "noise" occurred 11 times, and the first article we identified as studying a stressor and a strain was focused on noise (Laird, 1933). Moreover, the second most highly cited article (see online Appendix B) during this time period was also focused on the impact of noise (Jerison, 1959).

Other aspects of industrialized work are reflected in the words. The word "accident" occurred five times, first in a book review of readings in industrial psychology in 1931 and later in an article by Davids and Mahoney (1957), one of the top 10 most cited stress articles during this era (online Appendix B). Interestingly, the word "shift" occurred only once in our database, suggesting that shift work was not a key concern, and the word "alienation" did not occur at all, suggesting that research in the first era does not foreshadow later issues and concerns with industrialization, such as the large-scale strikes in 1946 (see Appendix A).

Theory. In terms of theory, this era is characterized by the concepts of homeostasis and physiological processes described by Cannon (1932) and Selye (1936). Evidence of the focus on physiological processes is present in Laird (1933) who in studying the effects of loud noise concluded that:

"Most unexpected and of greatest significance, however, was the great increase in the volume of urine excreted at the level of 80 and 90 decibels. This is in 
harmony, however, with the work of Corbeille on changes in the volume of the kidney and spleen of dogs under different noise influences. This observation is being made the subject of special study and is in line with the hypothesis that the effects of noise are due largely to the appropriate noise causing a biological fear reaction" (p. 329).

In many ways, however, Laird (1933) was the exception rather than the rule in terms of showing links to theory. Words such as "homeostasis" are not mentioned once during this era, and the word "physiological" and its variants occur six times, only in book reviews.

\section{The 1967-1996 Era}

The middle columns in Table 1 present the 25 most frequent words in abstracts between 1967 and 1996, a period during which stress research emerged as a central topic in JAP. The frequency pattern of words in the era between 1967 and 1996 differs dramatically from the previous era in that "job", "stress", and "work" are the three most common words. The word frequency pattern also reflects a pronounced move away from book reviews and towards empirical studies, as reflected by words such as "result(s)", "analys(es)","data," and "model". In addition, the word frequencies reveal clear patterns with respect to outcome variables. For instance, the words "performance", "satisfaction", and "health" were common. Based on the usage patterns, the 30 year period from 1967 to 1996 represents a critical milestone introducing new theoretical and empirical paradigms for stress research.

Societal trends: Women in workplace. Of the societal trends during this era; perhaps none is more important than the large increase of women in the work force between 1960 and 1980. Articles from 1967 to 1996 suggest that this trend is viewed fundamentally differently than when women joined the workforce during the World wars. A clear example of an article 
examining stress and women is Chacko (1982), who focused on Title VII of the Civil Rights Act and the preferential recruitment and hiring of women, exploring "the relationships between perceived preferential selection and several organizational outcome variables such as organizational commitment, role stress, and satisfaction." Another theme during this era was to examine gender differences in work characteristics such as job control (Adelmann, 1987) and coping (Parkes, 1990). These articles stand in contrast with studies of women in the previous era. One such study from the previous era examined fatigue among women involved in house care (Gross and Bartley, 1951). Selection criteria for participants in that study included being "the mother of at least one child" (p. 205) and "in the habit of doing their own cleaning" (p. 205-206).

Societal trends: Economic uncertainty. The era from 1967 to 1996 did not have any economic impact that earned the title "great" as in "great depression" or "great recession"; nonetheless, this period had a number of significant economic shocks, including the Arab Oil Embargo, the Chrysler Bailout, the highest unemployment rate (10.4\%) since 1940, and the Savings and Loan Bailout (see Appendix A). Unlike the previous era, there are clear signs that these economic events were reflected in published research. For instance, in our sample of articles, the word "unemployed" occurs 15 times representing eight studies. The highly cited study by Caplan, Vinokur, Price, and Van Ryn (1989) is a noteworthy randomized field experiment promoting motivation to seek reemployment (online Appendix C).

Societal trends: Stress and Safety. While history has witnessed numerous occupational disasters, the period between 1967 and 1996 was characterized by several particularly noteworthy events. In 1984, the Bhopal gas tragedy is estimated to have killed up to 16,000 . In 1986, the Chernobyl disaster killed only 31, but released massive amounts of radiation that continues to have negative effects on citizens. Finally, in 1987 the USS Stark was struck by two 
missiles fired by an Iraqi jet and the ensuing damage and loss of life garnered considerable media attention. The tragedies obviously had multiple causes; however, there was broad recognition that high levels of stress were often a mitigating factor in a wide variety of safety accidents. Indeed, even at a national level the link between stress and safety had been drawn earlier in the era in 1970 when the US established the National Institute for Occupational Safety and Health (NIOSH). Several JAP publications during this era reflect the interest in the role of stress and safety. For instance, one of the top 10 most cited articles from this era is Wright (1974) who focused on time pressure (a stressor) and decision making. Another noteworthy line of research was funded by the Navy partially in response to the USS Stark incident and specifically focused on stress and decision making within teams (e.g., Driskell \& Salas, 1992).

Theoretical advances: Role stress. As noted, the 1967 to 1996 era presented significant developments in stress theory. Table 1 shows that terms related to role stress theory (Kahn \& Quinn, 1970) were common, with the word "role" occurring 108 times in the abstracts $\left(8^{\text {th }}\right.$ overall). The first article in our sample that used the word "role" with respect to role stress theory was House and Rizzo (1972). This study used measures of role conflict and role ambiguity as criteria when evaluating a measure of organizational climate. As such, this study deviates from the typical design, in which role stress is cast as a predictor of outcomes such as well-being. The distinction of being the first role stress study to include stressors and strains belongs to Hamner and Tosi (1974), who examined the link between role stress and indices of well-being in 61 high-level managers.

As suggested by Table 1, numerous other studies focused on aspects of role stress theory during this era. Two articles were particularly influential as indexed by citation rates. The first was Beehr, Walsh and Taber (1976)'s examination of the moderating effects of higher-order 
need strength in the relationships among role stressors, individual strains, and organizationally valued states, such as involvement. The second was Caplan and Jones' (1975) study of the moderating effect of Type A personality (online Appendix C).

Theoretical advances: Social support. The era from 1967 to 1996 also focused on identifying moderators of links between stressors, perceived stress, and strains. While a number of individual factors such as personality and coping styles were examined, the word frequency analysis suggests that social support was particularly prevalent (while treated as separate, the words "social" and "support" had a frequency correlation of $r=.70$ ). The first study to examine social support as a direct effect and moderator in our database was Caplan, Cobb, and French (1975), which focused on smoking cessation in the workplace (thereby capturing another relevant societal trend).

Three studies of social support that were particularly highly cited were Ganster, Fusilier, and Mayes (1986); Russell, Altmaier, and Van Velzen (1987), and Etzion (1984). Ganster et al. (1986) is noteworthy because the main finding was the absence of a moderating effect for social support. This null finding reflects a general tendency for moderating effects to be more elusive than main effects in social support research (and stress research in general). Both Russell et al. (1987) and Etzion (1984) focused on social support as a predictor and moderator of burnout. While the term "burnout" was not identified as one of the top 25 words in the second era, the word frequency analyses from the next era shows that the origins of burnout research can be traced to the middle era. A final article that deserves mention was the seminal article by Eisenberger, Huntington, Hutchison, and Sowa (1986) introducing the construct of "positive organizational support” (POS) - a construct that has been highly influential and widely examined during this era and the next (see online Appendices C and D). 
Theoretical advances: Moderation. While social support was arguably the key moderator of the second era, it is clear that studies of moderation (in general) were prevalent. Variants of the word "moderate" occurred in 36 articles, and even though this frequency is not high enough to put the word among the top 25 in Table 1, it nonetheless demonstrates interest in factors that buffered the relationship between stressors and strains. Moreover, some authors discussed moderating effects without using the term "moderator": Caplan and Jones (1975), for instance, referred to Type-A behavior as a "conditioner" rather than a moderator of the effects of role stress on strains.

\section{The Era from 1997 to the Present}

The word frequency from 1997 to the present is, in many ways, similar to that of the previous era. Many themes from the previous era carried over (e.g., role stress, support); at the same time, new themes emerged, leading to a general increase in the total percent of articles focused on stress and well-being. Given complexity of the wordcloud for this era (Figure 2), it is important to expand our coverage and consider words beyond those listed in the top 25 words in Table 1; therefore, we rely more on words that were listed in the wordcloud which occur with a frequency of $25 \%$ of total articles (i.e., 55 times or more).

Despite the similarities between the second and third eras, several noteworthy distinctions are evident. First, the word "stress" drops from second most frequent in the second era to the $23^{\text {rd }}$ most frequent word in the current era. The drop may reflect increased specificity in the terminology. That is, instead of generically using the word "stress" to refer to both the causal event and the outcome, researchers appear to have been more careful in delineating between the words "stressor" $(n=96)$ and "strain" $(n=69)$.

Second, "satisfaction" dropped out of the top 25, and the word "emotional" emerged. The 
expanded list of words that occur at least 55 times includes the terms "exhaustion", $(\mathrm{n}=84)$ and "burnout" $(\mathrm{n}=78)$. These patterns suggest an overall change and expansion in the nature of strains. ${ }^{2}$ Third, for the first time, the word "family" ranked in the top 25, and the word "conflict" occurred in the expanded set of words (86 times). We discuss the emergence of the word "family" in terms of broader societal trends, but the terms clearly indicate increased interest in conflict between work and family.

Societal trends: Work boundaries. Although the effects of current trends can be difficult to forecast, we anticipate that technological changes that are blurring the lines between work and non-work will be seen as defining characteristics of the early 2000 s. This theme is manifested in numerous ways. For instance, while the first two articles examining work-family conflict were published in 1994 and 1995, the topic greatly expanded in the current era. In a similar vein, the concept of "recovery" occasionally appeared in the journal, with the first instance in an examination of acute recovery related to sleep deprivation among pilots (Dowd, 1974) and then three times more in the 1990s. However, in the 2000s, frequency increased, with ten studies examining detaching from work during non-work periods (vacations, weekends, free evenings, etc.). Stress associated with the blurring of work and non-work boundaries is also captured by the emergence of the word "detachment," which occurred 30 times during this era (e.g., Etzion, Eden, \& Lapidot, 1998). Finally with respect to work boundaries, four of the top 25 most cited articles in this era (online Appendix D) centered on work-family conflict (e.g., Ford, Heinen, \& Langkamer, 2007; Frone, 2000; Judge \& Colquitt, 2004; Major, Klein, \& Ehrhart, 2002). Clearly the study of work stress in the current era has expanded beyond the workplace into broader aspects of life.

\footnotetext{
${ }^{2}$ Note that the word "emotional" reflects strain as in "emotional exhaustion" and stressor as in "emotional labor".
} 
Societal trends: Work tensions. Although the words "harassment," "aggression," and "incivility" did not appear in Table 1 nor in the expanded list, these topics are important when indexed by article citations (online Appendix D). For instance, the tenth most cited article is an examination of the antecedents and consequences of sexual harassment by Fitzgerald, Drasgow, Hulin, Gelfand, and Magley (1997), and the attention garnered by this study likely reflects broad societal issues surrounding workforce diversity along with the recognition that conflict in work settings has important implications for employee well-being.

Societal trends: Burnout. One can debate whether use of the words "burnout" and "emotional exhaustion" reflect something about the broader societal milieu or about advances in theory surrounding work stress. Nevertheless, one cannot deny the importance of the burnout construct within the current era. In addition to the increased prevalence of the words "burnout" and "exhaustion" mentioned earlier, six of the top 25 most highly cited articles in this era and four of the most highly cited articles in the previous era focus on some aspect of burnout (see online Appendices $\mathrm{C}$ and D). From the current vantage point, it appears that burnout and its variants have become prominent strains in the study of stress and well-being. Possibly, the workrelated nature of the burnout construct has made it an attractive outcome measure for researchers addressing job stress.

Theoretical advances: Resources. As noted, many of the theoretical ideas proposed and tested in the previous era continue to be refined during the current era. Role stress theory, in particular, continued to be influential as indicated by the word "role" in Table 1. The current era also appears to be one in which COR theory (Hobfoll, 1989) was frequently used as a theoretical framework. COR theory was first referenced by Lee and Ashford (1996) during the previous era in a widely cited meta-analysis of predictors of burnout (online Appendix C), but the word 
"resources" occurs 82 times in the current era. The importance of resources in stress and wellbeing research is also reflected by the most highly cited article in this era (Demerouti, Bakker, Nachreiner, \& Schaufeli, 2001).

Theoretical advances: Multilevel models. While advances in statistical methods do not formally constitute theory development, methods do play a key role in researchers' ability to test theory. The 1990's brought important methodological advances for analyzing hierarchically nested and longitudinal data (e.g., Bryk \&Raudenbush, 1992), and methods referred to as multilevel" or "mixed-effects" models were widely adopted. Consistent with these developments, the words "level(s)", and "time" emerged in Table 1, reflecting the increased reliance on multilevel and longitudinal approaches. Furthermore, several of the highly cited articles during this era (e.g., Jex \& Bliese, 1999) relied on these approaches for modeling shared group-level constructs such as collective efficacy (online Appendix D). In addition, the withinperson variant of these approaches became a standard analytic approach for examining phenomena such as recovery processes in experience sampling designs (Sonnentag, Binnewies, \& Mojza, 2008).

\section{Summary and Status of Theory}

Research on stress and well-being has been present since the inception of $J A P$. Over time, however, this line of research has increased and currently approaches $20 \%$ of journal space (see Figure 1). We see several reasons for this increase. First, JAP research has become increasingly reflective of broader societal events. Second, researchers have operationalized many stress-related theoretical concepts and applied them to work contexts. Third, new measures and statistical approaches have proven useful in the study of stress and well-being.

\section{Reflecting Societal Trends}


Overall, it is clear that publications in $J A P$ reflect larger societal trends, and it appears the journal has become increasingly synchronized with current events. It was not initially clear, however, which events would be reflected in the journal. For instance, we expected that links between "war" and "stress" would have been more pronounced given Hall's 1917 editorial and a series of major conflicts over 100 years including two World Wars; the Korean War, the Vietnam War, and wars in Iraq and Afghanistan. Unexpectedly, though, the term "war" occurred infrequently throughout the time frame of our review. In recent years, the distinctions between clinical and applied psychology are more strongly defined than in the early years of the journal; therefore, one might expect a lack of war-related research in more recent years as outcomes of war stress are seen as clinical problems. Indeed, a PsychInfo search of the term "post-traumatic stress disorder" indicated that articles on this topic are published most frequently in journals such as Military Medicine, the Journal of Mental Science, the British Journal of Psychiatry, and Psychosomatic Medicine. In early years, though, where clinical and applied boundaries were less clearly delineated, it seems somewhat surprising that the topic was rarely addressed..

While the topic of war stress did not gain much attention in JAP, other societal events certainly attracted interest and links to these events strengthened over time. For example, we found little evidence during the Great Depression (1929 to 1939) that concurrent societal trends such as unemployment were of interest to $J A P$ authors. In contrast, during 30-year era from 1967 to 1996, there were clear links to trends such as high unemployment and women entering the workforce. During the past 50 years, it is also apparent that technological changes that affect the workplace are reflected $J A P$.

One reason why $J A P$ might reflect some societal trends more than others is that stress researchers have increasingly focused on white-collar and service-related employees rather than 
blue-collar employees. The early writings of Fish (1917) and Martin (1917) addressed bluecollar workers, and research on topics such as the effects of noise (Laird, 1933; Jerison, 1959) took place in industrial settings. Stress research during the past 50 years, however, has tended to emphasize issues relevant to white-collar, professional workers and to employees in servicerelated jobs. One way to characterize the shift is to examine words that reflect outcomes over the three eras: The only clear outcome to register at a rate of $25 \%$ of the total publications in the first era was "fatigue" -- a term that often applied to manual labor. In contrast, in the second era two clear outcomes occurred with high frequency, "performance" and "satisfaction". In the third era, however, six clear outcomes are identifiable ("burnout", "exhaustion”, "health”, "performance", "satisfaction", and "strain"). By the third era, the list of outcomes tends to be more differentiated and clearly reflects increases in terms related to professional and servicerelated occupations.

There are at least two explanations for the field's emphasis on professional and servicerelated occupations. First, in many Western societies the number of white-collar and service jobs relative to blue-collar jobs has increased. Second, key theoretical constructs, such as role stress, emotional exhaustion, and burnout may be easier to collect and particularly relevant to white collar and service-related populations. One consequence of this shift in focus is that societal trends such as high unemployment may increasingly be reflected in $J A P$ because researchers are already studying populations likely to be impacted by the events.

A final observation concerns the degree to which publications in $J A P$ reflect global issues. For the most part, JAP articles have centered on phenomena observed in North American and, to a lesser extent, certain European and Asian societies. Although the prevalence of stress research using samples from outside North America has increased, it remains relatively rare in 
$J A P$. From a more global perspective, studies focusing on job stress in Latin America, Africa, and Arab countries as well as on processes related to global migration still need to find their way into $J A P$.

\section{Theory}

As alluded to, a second reason why work stress research has become increasingly prevalent in $J A P$ is that many of the key theoretical constructs and models proposed in the broader domain of stress research can be readily applied to the work context. From our review of $J A P$ trends, it is clear that influential theories from outside of the work domain influenced the study of work stress. These influences are apparent in seminal theories of work stress developed in the 1960s and 1970s, most notably role stress theory (Kahn et al., 1964), and had a dramatic impact on subsequent research published in JAP. It appears that the most influential theories are those whose key elements: (a) are work specific, such as role ambiguity and role conflict; (b) can be readily measured, as exemplified by the widely-used measures of role stress developed by Rizzo, House, and Lirtzman (1970); and (c) are relevant to white-collar and service-related populations.

Perhaps one reason why research on stress and well-being appears fractured during the first 50 years of the journal is that, during that time, stress theories focused largely on physiological processes. Such theories were difficult to operationalize in the work context and so, to a certain extent, they had little influence on stress research at work. Interestingly, many of the methodological tools used by researchers in the second era, such as surveys and correlational analyses, were available during the first era, so theory rather than method appears to be the most parsimonious explanation of the relative dearth of early stress research.

\section{Advances in Research Methods}


A third factor that might explain the increase in stress research involves methodological advances in measurement and data analysis. From a broad perspective, it is clear that early research focused on foundational work such as the measurement of certain key constructs to include fatigue. Therefore, when new theoretical models were proposed, researchers had already developed a measurement foundation upon which to operationalize constructs to test theoretical propositions.

In a similar way, techniques such as mixed-effects models (Bryk \& Raudenbush, 1992), which were initially applied in educational settings to study students in classrooms, were naturally generalized to research on stress and well-being in occupational settings. Variants of mixed-effects models that apply to individual processes over time and allow for longitudinal analyses have also been valuable (Zapf, Dormann, \& Frese, 1996). Other noteworthy statistical developments include the use of polynomial regression in research on the person-environment fit approach to stress (e.g., Edwards \& Harrison, 1993) and advances in tests of mediation to examine basic processes underlying models of stress (Edwards \& Lambert, 2007; MacKinnon, 2008). We anticipate that researchers will continue to apply future advances in statistics to study the fundamentally complex, multi-cause stress processes that unfold over time.

\section{Conclusion and Future Trends}

The fundamental idea expressed by Fish in 1917 that the "shop shall be comfortable in both a physical and a mental way" (p. 162) is clearly more germane to the core of JAP in 2017 than it was in 1917. Over the last 100 years, concepts of what constitutes the "shop" have changed in ways that few could have foreseen. Likewise, concepts of what it means to be "comfortable in both a physical and mental way" have changed reflecting increasing interest in the psychological impact of non-physical work stressors such as role stress linked to strains such 
as burnout and emotional exhaustion. It is important to note, however, that while the traces of stress research where present in 1917, it took advances in theory to serve as the spark that ignited the research topic area. By themselves, societal events (even momentous events like world wars) failed to drive research; rather, the catalyst was provided by theorists who presented interesting, relevant, and testable propositions. Looking ahead, we anticipate three trends that are particularly likely to stimulate the development, testing, and refinement of stress theory: (1) integration of physiological data; (2) ability to test work-life-cycle models, and (3) stress management trials. Integration of Physical and Physiological Data. Interestingly, in a potential return to elements of the past, technological advances in sensors continue to make the collection of physical and physiological data streams increasingly feasible in applied settings. We believe that it is likely that streams of data from sensors will capture even broader ranges of both stressors (e.g., physical exertion, noise, ambient temperature) and strains (e.g., sleep quantity and quality, body temperature, endocrine markers) that will further allow the field to refine knowledge of the stress process (e.g., Dettenborn, Tietze, Bruckner, \& Kirschbaum, 2010). At the same time, as sensor-related data progresses the field is almost certain to require significant theoretical advances to integrate the information into testable, relevant hypotheses.

Work-Life-Cycle Models. Second, we foresee the development and maintenance of work-life cycle longitudinal databases focusing on work stressors, moderators, mediators, and strains. Work-life-cycle data will allow researchers to test and refine process-related theories about stress, coping, and well-being over extended periods of time (see also, Cummings \& Cooper, 1979; Edwards, 1992). Although many stress theories posit a cyclical relationship between stress and coping, most empirical research has taken a more static view, a shortcoming that can and should be overcome in future research. 


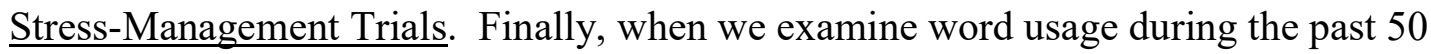
years, words such as "relationship(s)," "related," and "effect(s)" frequently emerged in the abstracts (see Table 1). The frequent use of these words reflects a general avoidance of causal language, as in "the relationship between the stressor and the strain was significant". Fundamentally, however, theories of stress are causal and, as such, should be tested with research designs that allow stronger causal inferences.

To some degree, one can argue that the roots of stress research lie in studies that allow for stronger causal inference. Recall that the first $J A P$ article we identified that included both a stressor and strain was Laird (1933) in an experiment study of loud noise. During the past 50 years, however, designs have been primarily quasi-experimental or correlational, in which studies have measured constructs and described relationships among stressors, moderators, and strains either at single points or, in limited instances, in longitudinal designs.

Obviously ethical issues preclude a executing a wide-range of studies randomly assigning individuals to different conditions involving stressors. In contrast, few if any unsurmountable ethical issues preclude conducting randomized trials focused on interventions designed to help employees cope with work stressors (i.e., stress management strategies). Importantly, however, well-designed randomized trials that would allow one to make causal inferences about stress management strategies continue to be rare. For instance, in 2008, Richardson and Rothstein published a meta-analysis on stress management intervention programs in which they identified only 38 articles between 1977 and early 2006 (approximately 1.3 a year). Of the 38, three were published in JAP (Bruning \& Frew, 1987; Ganster, Mayes, Sime \& Tharp, 1982; Jackson, 1983).

One consequence of having few studies focused on stress management interventions is that we, as a field, are then limited in our ability to develop and refine theory surrounding 
implementation science - an area of research becoming increasingly important in public health (e.g., Bammer, 2005). Thus, in concluding our 100 year review of research on stress and wellbeing, we anticipate that theory and research can continue to evolve in ways that support stronger causal inference, and more specifically that the field will continue to develop and test research and theory that provide actionable knowledge to help organizations manage the diverse and unpredictable stressors that will emerge over the next 100 years. 


\section{References}

Adelmann, P. K. (1987). Occupational complexity, control, and personal income: Their relation to psychological well-being in men and women. Journal of Applied Psychology, 72, 529537.

Anderson, R. G. (1949). Reported and demonstrated values of vocational counseling. Journal of Applied Psychology, 33, 460-473.

Bammer G: Integration and Implementation Sciences: building a new specialization. Ecology and Society 2005, 10:6

Beehr, T. A., \& Newman, J. E. (1978). Job stress, employee health, and organizational effectiveness: a facet analysis, model, and literature review. Personnel Psychology, 31, 665-699.

Beehr, T. A., Walsh, J. T., \& Taber, T. D. (1976). Relationships of stress to individually and organizationally valued states: Higher order needs as a moderator. Journal of Applied Psychology, 61, 41-47.

Bhagat, R. S. (1983). Effects of stressful life events on individual performance effectiveness and work adjustment processes within organizational settings: A research model. Academy of Management Review, 8, 660-671.

Bhagat, R. S., McQuaid, S. J., Lindholm, H., \& Segovis, J. (1985). Total life stress: A multimethod validation of the construct and its effects on organizationally valued outcomes and withdrawal behaviors. Journal of Applied Psychology, 70, 202-214.

Bruning, N. S.; \& Frew, D. R. (1987). Effects of exercise, relaxation, and management skills training on physiological stress indicators: A field experiment. Journal of Applied Psychology, 72, 515-521. 
Bryk, A. P., \& Raudenbush, S. W. (1992). Hierarchical linear models. Newbury Park, CA: Sage.

Cannon, W. B. (1915). Bodily changes in pain, hunger, fear and rage: An account of recent researches into the function of emotional excitement. New York: Appleton.

Cannon, W.B. (1932). The wisdom of the body. New York: Norton.

Caplan, R. D., Cobb, S., \& French, J. R. (1975). Relationships of cessation of smoking with job stress, personality, and social support. Journal of Applied Psychology, 60, 211-219.

Caplan, R. D., \& Jones, K. W. (1975). Effects of work load, role ambiguity, and Type A personality on anxiety, depression, and heart rate. Journal of Applied Psychology, 60, 713-719.

Caplan, R. D., Vinokur, A. D., Price, R. H., \& Van Ryn, M. (1989). Job seeking, reemployment, and mental health: A randomized field experiment in coping with job loss. Journal of Applied Psychology, 74, 759-769.

Cavanaugh, M. A., Boswell, W. R., Roehling, M. V., \& Boudreau, J. W. (2000). An empirical examination of self-reported work stress among U.S. managers. Journal of Applied Psychology, 85, 65-74.

Chacko, T. I. (1982). Women and equal employment opportunity: Some unintended effects. Journal of Applied Psychology, 67, 119-123.

Cohen, S., \& Edwards, J. R. (1989). Personality characteristics as moderators of the relationship between stress and disorder. In W. J. Neufeld (Ed.), Advances in the investigation of psychological stress: 235-283. New York: Wiley.

Cohen, S., \& Wills, T. A. (1985). Stress, social support, and the buffering hypothesis. Psychological Bulletin, 98, 310-357. 
Cooper, C. L., \& Dewe, P. (2004). Stress: A brief history. Oxford: Blackwell.

Cooper, C. L. , \& Marshall, J. (1976). Occupational sources of stress: A review of the literature relating to coronary heart disease and mental ill health . Journal of Occupational Psychology, 49, 11-28

Cummings, T. G., \& Cooper, C. L. (1979). A cybernetic framework for studying occupational stress. Human Relations, 32, 395-418.

Davids, A., \& Mahoney, J. T. (1957). Personality dynamics and accident proneness in an industrial setting. Journal of Applied Psychology, 41, 303-306.

Davis, L. E., \& Taylor, J. C. (Eds.). (1972). The design of jobs. London: Penguin.

Demerouti, E., Bakker, A. B., Nachreiner, F., \& Schaufeli, W. B. (2001). The job demandsresources model of burnout. Journal of Applied Psychology, 86(3), 499-512.

Dettenborn, L., Tietze, A., Bruckner, F., \& Kirschbaum, C. (2010). Higher cortisol content in hair among long-term unemployed individuals compared to controls. Psychoneuroendocrinology, 35, 1404-1409.

Dewe, P. J., O'Driscoll, M. P., \& Cooper, C. L. (2010). Coping with work stress: A review and critique. John Wiley \& Sons.

Dohrenwend, B. S., \& Dohrenwend, B. P. (1981). Stressful life events and their contexts. New York: Neale Watson.

Dohrenwend, B. P. (2006). Inventorying stressful life events as risk factors for psychopathology: Toward resolution of the problem of intracategory variability. Psychological Bulletin, $132,477-495$.

Dowd, P. J. (1974). Sleep deprivation effects on the vestibular habituation process. Journal of Applied Psychology, 59, 748-752. 
Driskell \& Salas, 1992

Edwards, J. R. (1992). A cybernetic theory of stress, coping, and well-being in organizations. Academy of Management Review, 17, 238-274.

Edwards, J. R., \& Harrison, R. V. (1993). Job demands and worker health: Three-dimensional reexamination of the relationship between person environment fit and strain. Journal of Applied Psychology, 78, 628-648.

Edwards, J. R., \& Lambert, L. S. (2007). Methods for integrating moderation and mediation: A general analytical framework using moderated path analysis. Psychological Methods, 12, $1-22$.

Eisenberger, R., Huntington, R., Hutchison, S., \& Sowa, D. (1986). Perceived organizational support. Journal of Applied Psychology, 71, 500-507.

Elwood, R. H. (1927). The role of personality traits in selecting a career: the nurse and the college girl. Journal of Applied Psychology, 11, 199-201.

Etzion, D. (1984). Moderating effect of social support on the stress-burnout relationship. Journal of Applied Psychology, 69, 615-622.

Etzion, D., Eden, D., \& Lapidot, Y. (1998). Relief from job stressors and burnout: Reserve service as a respite. Journal of Applied Psychology, 83, 577-585.

Fish, E. H. (1917). Human engineering. Journal of Applied Psychology, 1, 161-174.

Feinerer, I., Hornik, K., \& Meyer, D. (2008). Text Mining Infrastructure in R. Journal of Statistical Software 25(5): 1-54. URL: http://www.jstatsoft.org/v25/i05/.

Fitzgerald, L. F., Drasgow, F., Hulin, C. L., Gelfand, M. J., \& Magley, V. J. (1997). Antecedents and consequences of sexual harassment in organizations: A test of an integrated model. Journal of Applied Psychology, 82, 578-589. 
Folkman, S., \& Lazarus, R. S. (1988). Manual for the Ways of Coping Questionnaire. Palo Alto, CA: Consulting Psychologists Press.

Ford, M. T., Heinen, B. A., \& Langkamer, K. L. (2007). Work and family satisfaction and conflict: A meta-analysis of cross-domain relations. Journal of Applied Psychology, 92, $57-80$.

French, J. R., Caplan, R. D., \& Van Harrison, R. V. (1982). The mechanisms of job stress and strain. New York: J. Wiley.

Frone, M. R. (2000). Work-family conflict and employee psychiatric discorders: The national comorbidity survey. Journal of Applied Psychology, 85, 888-895.

Gajendran, R. S., \& Harrison, D. A. (2007). The good, the bad, and the unknown about telecommuting: Meta-analysis of psychological mediators and individual consequences. Journal of Applied Psychology, 92, 1524-1541.

Gallie, D. (2003). The quality of working life: Is Scandinavia different. European Sociological Review, 19, 61-79.

Ganster, D. C., Fusilier, M. R., \& Mayes, B. T. (1986). Role of social support in the experience of stress at work. Journal of Applied Psychology, 71, 102-110.

Ganster, D. C., Mayes, B. T., Sime, W. E., \& Tharp, G. D. (1982). Managing occupational stress: A field experiment. Journal of Applied Psychology, 67, 533-542.

Ganster, D. C., \& Schaubroeck, J. (1991). Work stress and employee health. Journal of Management, 17, 235-271.

Ganster, D. C., Schaubroeck, J., Sime, W. E., \& Mayes, B. T. (1991). The nomological validity of the Type A personality among employed adults. Journal of Applied Psychology, 76, 143-168. 
Garth, T. R. (1920). Racial differences in mental fatigue. Journal of Applied Psychology, 4, 235244.

Gross, I. H., \& Bartley, S. H. (1951). Fatigue in house care. Journal of Applied Psychology, 35, 205-207.

Hall, G. S. (1917). Practical relations between psychology and the war. Journal of Applied Psychology, 1, 9-16.

Hamner, W. C., \& Tosi, H. L. (1974). Relationship of role conflict and role ambiguity to job involvement measures. Journal of Applied Psychology, 59, 497-499.

Higgins, C. A., Duxbury, L. E., \& Irving, R. H. (1992). Work-family conflict in the dual-career family. Organizational Behavior and Human Decision Processes, 51, 51-75.

Hobfoll, S. E. (1989). Conservation of resources: A new attempt at conceptualizing stress. American Psychologist, 44, 513-524.

Holmes, T. H., \& Rahe, R. H. (1967). The social readjustment rating scale. Journal of Psychosomatic Research, 11, 213-218.

House, J. S. (1981). Work stress and social support. Reading, PA: Addison-Wesley.

House, R. J., \& Rizzo, J. R. (1972). Toward the measurement of organizational practices: Scale development and validation. Journal of Applied Psychology, 56, 388-396.

Jackson, S. E. (1983). Participation in decision making as a strategy for reducing job-related strain. Journal of Applied Psychology, 68, 3-19. doi:10.1037/0021-9010.68.1.3

Jerison, H. J. (1959). Effects of noise on human performance. Journal of Applied Psychology, 43, 96-101.

Jex, S. M., Beehr, T. A., \& Roberts, C. K. (1992). The meaning of occupational stress items to survey respondents. Journal of Applied Psychology, 77, 623-628. 
Jex, S. M., \& Bliese, P. D. (1999). Efficacy beliefs as a moderator of the impact of work-related stressors: A multilevel study. Journal of Applied Psychology, 84, 349-361.

Judge, T. A., \& Colquitt, J. A. (2004). Organizational justice and stress: The mediating role of work-family conflict. Journal of Applied Psychology, 89, 395-404.

Kahn, R. L., \& Byosiere, P. (1992). Stress in organizations. In M. D.Dunnette \& L. M.Hough (Eds.), Handbook of industrial and organizational psychology (2nd ed., Vol. 3, pp. 571650). Palo Alto, CA: Consulting Psychologists Press, Inc.

Kahn, R. L., \& Quinn, R. P. (1970). Role stress: A framework for analysis. In McLean (Ed.), Occupational mental health (pp. 50-115). Chicago: Rand McNally.

Kahn, R. L., Wolfe, D. M., Quinn, R. P., Snoek, J. D., \& Rosenthal, R. A. (1964). Organizational stress: Studies in role conflict and ambiguity. New York: Wiley.

Karasek, R. A., Jr. (1979). Job demands, job decision latitude, and mental strain: Implications for job redesign. Administrative Science Quarterly, 24, 285-311.

Kessler, R. C., Price, R. H., \& Wortman, C. B. (1985). Social factors in psychopathology: Stress, social support, and coping processes. Annual Review of Psychology, 36, 531-572.

Kornhauser, A. (1965). Mental health of the industrial worker. New York: Wiley.

Latack, J. C., \& Havlovic, S. J. (1992). Coping with job stress: A conceptual evaluation framework for coping measures. Journal of Organizational Behavior, 13, 479-508.

Latack, J. C., Kinicki, A. J., \& Prussia, G. E. (1995). An integrative process model of coping with job loss. Academy of Management Review, 20, 311-342.

Laird, D. A. (1933). The influence of noise on production and fatigue, as related to pitch, sensation level, and steadiness of the noise. Journal of Applied Psychology, 17, 320-330.

Lazarus, R. S. (1966). Psychological stress and the coping process. New York: McGraw-Hill. 
Lazarus, R. S. (1993). Coping theory and research: Past, present, and future. Psychosomatic Medicine, 55, 234-247.

Lazarus, R. S., Averill, J. R., \& Opton, E. M., Jr. (1974). The psychology of coping: Issues of research and assessment. In G. V. Coelho, D. A. Hamburg, \& J. E. Adams (Eds.), Coping and adaptation (pp. 249-315). New York: Basic Books.

Lazarus, R. S., \& Folkman, S. (1984). Stress, appraisal, and coping. New York: Springer.

Lee, R. T., \& Ashforth, B. E. (1996). A meta-analytic examination of the correlates of the three dimensions of job burnout. Journal of Applied Psychology, 81, 123-133.

LePine, J. A., LePine, M. A., \& Jackson, C. L. (2004). Challenge and hindrance stress: Relationships with exhaustion, motivation to learn, and learning performance. Journal of Applied Psychology, 89, 883-891.

MacKinnon, D. P. (2008). Introduction to statistical mediation analysis. Hillsdale, NJ: Erlbaum.

Major, V. S., Klein, K. J., \& Ehrhart, M. G. (2002). Work time, work interference with family, and psychological distress. Journal of Applied Psychology, 87, 427-436.

Marino, K. E., \& White, S. E. (1985). Departmental structure, locus of control, and job stress: The effect of a moderator. Journal of Applied Psychology, 70, 782-784.

Martin, L. J. (1917). Mental hygiene and the importance of investigating it. Journal of Applied Psychology, 1, 67-70.

Mason, J. W. (1975a). A historical view of the stress field: Part I. Journal of Human Stress, 1, 6-12.

Mason, J. W. (1975b). A historical view of the stress field: Part II. Journal of Human Stress, 1, 22-36. 
McGrath, J. E. (1970). Social and psychological factors in stress. New York: Holt, Rinehart \& Winston.

Mullen, B., \& Suls, J. (1982). "Know thyself”: Stressful life changes and the ameliorative effect of private self-consciousness. Journal of Experimental Social Psychology, 18, 43-55.

Murphy, L. R. (2002). Job stress research at NIOSH: 1971-2002. Research in occupational stress and well-being: Historical and current perspectives on stress and health, 2, 1-55. doi: $10.1016 / \mathrm{S} 1479-3555(02) 02001-2$

Parkes, K. R. (1990). Coping, negative affectivity, and the work environment: Additive and interactive predictors of mental health. Journal of Applied Psychology, 75, 399-409.

Parkes, K. R. (1994). Personality and coping as moderators of work stress processes: Models, methods and measures. Work \& Stress, 8, 110-129.

Pugliesi, K. (1999). The consequences of emotional labor: Effects on work stress, job satisfaction, and well-being. Motivation and Emotion, 23, 125-154.

R Core Team (2014). R: A language and environment for statistical computing. R Foundation for Statistical Computing, Vienna, Austria. URL http://www.R-project.org/.

Richardson, K. M., \& Rothstein, H. R. (2008). Effects of occupational stress management intervention programs: A meta-analysis. Journal of Occupational Health Psychology, 13, 69-93. doi: 10.1037/1076-8998.13.1.69

Rizzo, J. R., House, R. J., \& Lirtzman, S. I. (1970). Role conflict and ambiguity in complex organizations. Administrative Science Quarterly, 150-163.

Russell, D. W., Altmaier, E., \& Van Velzen, D. (1987). Job-related stress, social support, and burnout among classroom teachers. Journal of Applied Psychology, 72, 269-274.

Selye, H. (1936). A syndrome produced by diverse nocuous agents. Nature, 138, 32. 
Schuler, R. S. (1980). Definition and conceptualization of stress in organizations. Organizational Behavior and Human Performance, 25, 184-215.

Shepard, J. M. (1977). Technology, alienation, and job satisfaction. Annual Review of Sociology, $3,1-21$.

Silbiger, A., \& Pines, A. M. (2014). Expatriate stress and burnout. The International Journal of Human Resource Management, 25, 1170-1183.

Sonnentag, S., Binnewies, C., \& Mojza, E. J. (2008). "Did you have a nice evening?" A daylevel study on recovery experiences, sleep, and affect. Journal of Applied Psychology, 93, 674-684.

Statista (2015). http://www.statista.com/statistics/273018/number-of-internet-users-worldwide/

Taubman, R. E. (1947). The special leadership training program at the signal corps officer candidate school. Journal of Applied Psychology, 31, 82-90.

Thoits, P. A. (1983). Dimensions of life events that influence psychological distress: An evaluation and synthesis of the literature. In H. B. Kaplan (Ed.), Psychological stress: Trends in theory and research (pp. 33-103). New York: Academic Press.

Vinokur, A., \& Selzer, M. (1975). Desirable versus undesirable life events: Their relationship to stress and mental distress. Journal of Personality and Social Psychology, 66, 297-333.

Viswesvaran, C., Sanchez, J. I., \& Fisher, J. (1999). The role of social support in the process of work stress: A meta-analysis. Journal of Vocational Behavior, 54, 314-334.

Wiersma, U. J. (1994). A taxonomy of behavioral strategies for coping with work-home role conflict. Human Relations, 47, 211-221.

Wright, P. (1974). The harassed decision maker: Time pressures, distractions, and the use of evidence. Journal of Applied Psychology, 59(5), 555-561. 
Zapf, D., Dormann, C., \& Frese, M. (1996). Longitudinal studies in organizational stress research: A review of the literature with reference to methodological issues. Journal of Occupational Health Psychology, 1, 145-169. 
Table 1: Top 25 Words in Abstracts by Era

\begin{tabular}{|c|c|c|c|c|c|}
\hline \multicolumn{2}{|c|}{ 1917-1966 Era $(n=173)$} & \multicolumn{2}{|c|}{ 1967-1996 Era $(\mathrm{n}=213)$} & \multicolumn{2}{|c|}{ 1997-Present $(n=220)$} \\
\hline Word & Count & Word & Count & Word & Count \\
\hline Book & 169 & job & 253 & work & 341 \\
\hline Mental & 131 & stress & 205 & job & 313 \\
\hline group(s) & 104 & work & 165 & study(ies) & 243 \\
\hline tests(s) & 90 & group $(\mathrm{s})$ & 152 & effect(s) & 217 \\
\hline psychology & 78 & effect(s) & 126 & employee(s) & 213 \\
\hline reviews & 64 & satisfaction & 117 & relationship(s) & 209 \\
\hline Group & 64 & performance & 109 & results & 161 \\
\hline scale(s) & 61 & role & 108 & related & 141 \\
\hline Work & 60 & results & 103 & performance & 135 \\
\hline problem(s) & 58 & significant(ly) & 96 & negative(ly) & 130 \\
\hline author(s) & 56 & related & 94 & individual(s) & 127 \\
\hline Fatigue & 54 & relationship(s) & 91 & level(s) & 126 \\
\hline Study & 52 & analys(es) & 85 & support & 120 \\
\hline child(ren) & 51 & measure(s) & 84 & emotional & 118 \\
\hline hygiene & 48 & support & 77 & behavior(s) & 115 \\
\hline personality & 41 & study & 71 & theor(etical) & 111 \\
\hline Part & 39 & social & 67 & time & 110 \\
\hline Social & 38 & organizational & 66 & examine(d) & 108 \\
\hline performance & 38 & control & 65 & positive(ly) & 108 \\
\hline students & 37 & factor(s) & 59 & psychological & 106 \\
\hline psychological & 35 & data & 59 & role & 104 \\
\hline college & 34 & model & 58 & health & 102 \\
\hline difference(s) & 32 & high & 58 & stress & 101 \\
\hline Results & 31 & employees & 56 & family & 100 \\
\hline individual & 31 & health & 53 & control & 98 \\
\hline
\end{tabular}


Figure 1: Percent of total articles meeting search criteria

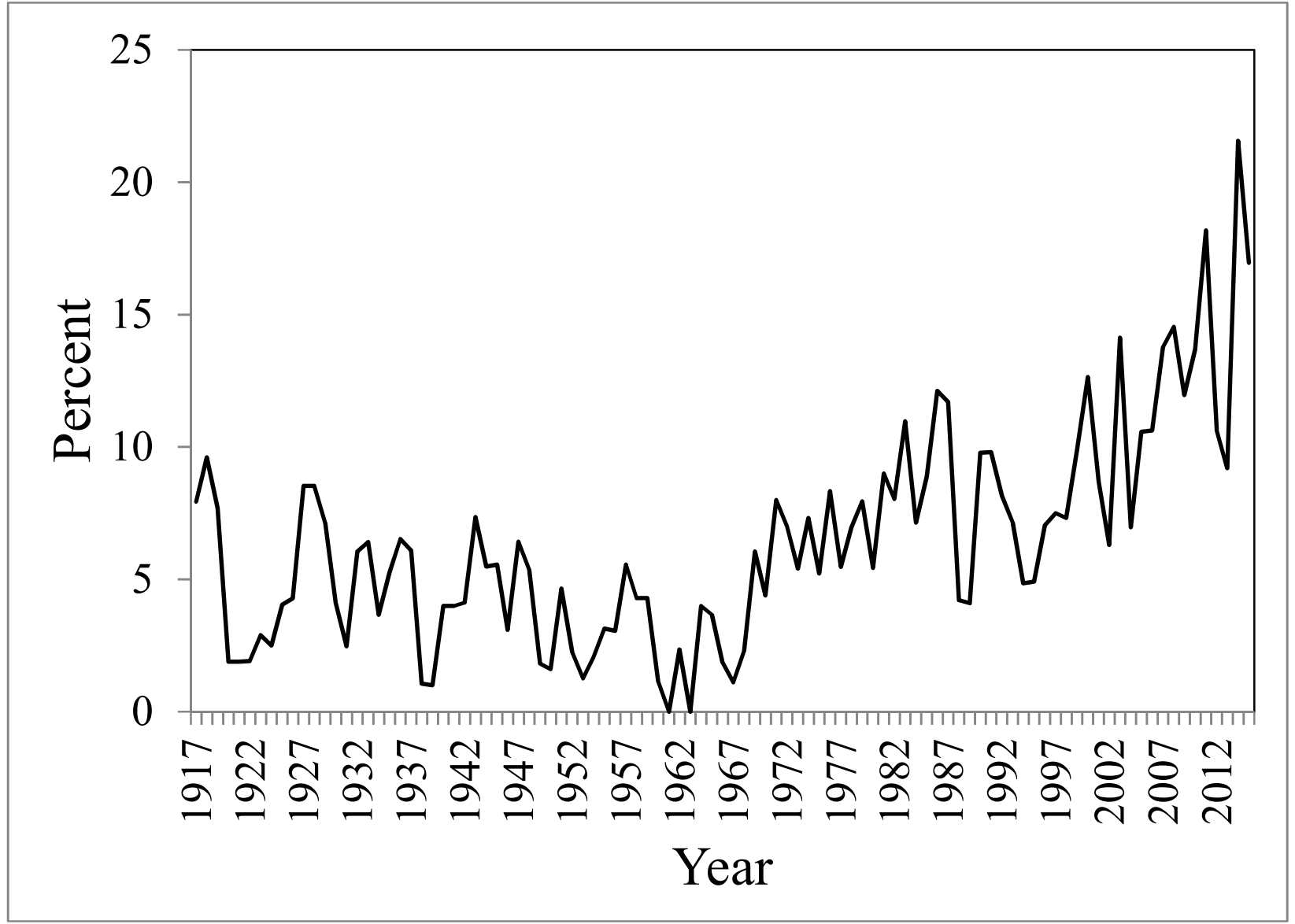


Figure 2: Wordclouds for three eras
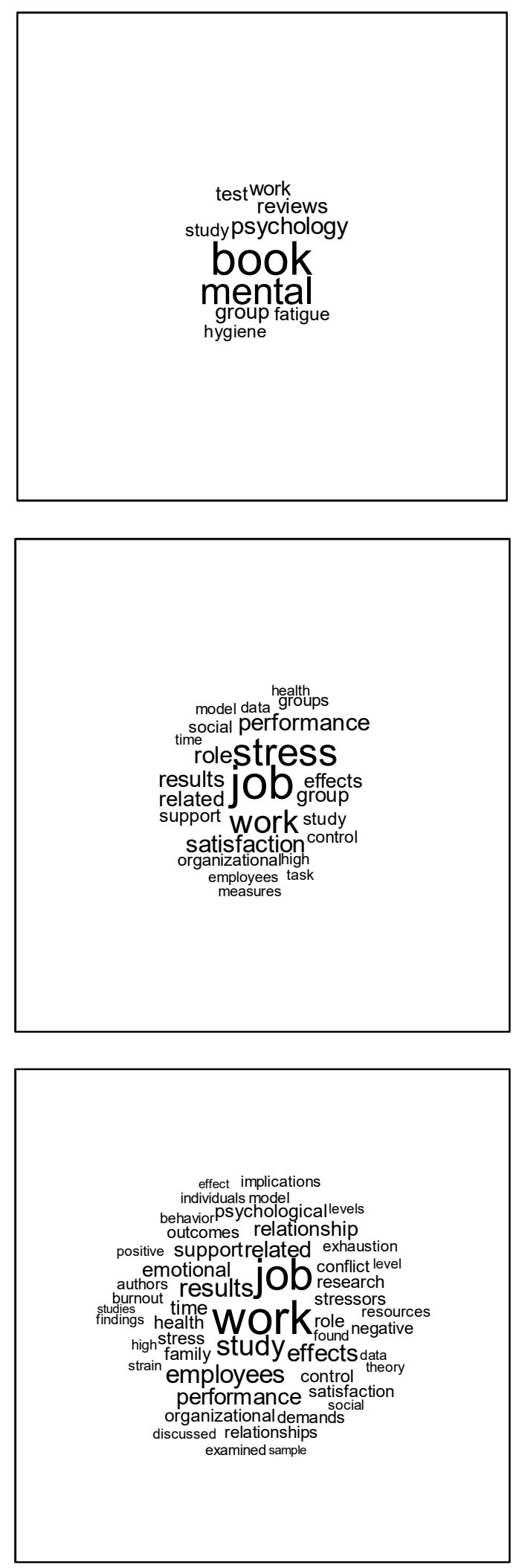
Online Appendix A: Key Historic Events with Implications for

Stress and Well-Being

(compiled from Wikipedia and http://americasbesthistory.com)

\begin{tabular}{|c|c|}
\hline 1917-1926 & $\begin{array}{ll}\text { - } & \text { US Enters WW I } \\
\text { - } & \text { Influenza epidemic }>500 K \text { killed in US (1918) } \\
\text { - } & \text { Prohibition (1919-1933) } \\
\text { - } & \text { Women given right to vote }(1920)\end{array}$ \\
\hline 1927-1936 & $\begin{array}{l}\text { - } \text { Stock Market crash and Great Depression Begins (1929) } \\
\text { - } \quad \text { Dust bowl (1933 / 34) } \\
\text { - } \quad \text { Social Security Act Passed (1935) }\end{array}$ \\
\hline 1937-1946 & $\begin{array}{ll}\text { - } & \text { National Minimum Wage (1938) } \\
\text { - } & \text { Great Depression Ends (1939) } \\
\text { - } & \text { First peacetime draft in US (1940) } \\
\text { - } & \text { Attack on Pearl Harbor (1941) } \\
\text { - } & \text { Hundreds of thousands of mine workers strike: spreads to other } \\
& \text { industries (1946) }\end{array}$ \\
\hline 1947-1956 & $\begin{array}{l}\text { - } \text { Segregation in the United States military ended (1948) } \\
\text { - The Korean War begins (1950) } \\
\text { - } \text { President Truman authorizes the seizure of United States steel mills to } \\
\text { avert a strike (1952) } \\
\text { - Fighting ceases in the Korean War (1953) } \\
\text { - Ray Kroc founds the idea for the McDonald's corporation (1954) } \\
\text { - The American Federation of Labor and the Congress of Industrial } \\
\text { Organizations merge to form the AFL-CIO with } 15 \text { million members } \\
\text { (1955) }\end{array}$ \\
\hline 1957-1966 & $\begin{array}{l}\text { - President Kennedy announces his intention to place a man on the moon } \\
\text { by the end of the decade (1961) } \\
\text { - Omnibus Civil Rights legislation is passed (1964) } \\
\text { - United States warplanes begin their bombing raids of Hanoi (1966) } \\
\text { - Medicare begins (1966) }\end{array}$ \\
\hline 1967-1976 & $\begin{array}{l}\text { - Vietnam War is at its height (1969) } \\
\text { - Advanced Research Projects Agency Network (ARPANET) is } \\
\text { developed (1969) } \\
\text { - Arab Oil Embargo (1973) }\end{array}$ \\
\hline $1977-1986$ & $\begin{array}{l}\text { - The Chrysler Bailout is approved by the federal government (1979) } \\
\text { - } \text { Partial core meltdown at Three Mile Island nuclear power plant (1979) } \\
\text { - IBM introduces the IBM-PC personal computer (1981) } \\
\text { - First Female Supreme Court Justice (1981) } \\
\text { - Highest unemployment rate since } 1940 \text { is recorded at } 10.4 \%(1982) \\
\text { - } \quad \text { Bhopal gas tragedy at least 3,700 killed; over 558,000 injuries (1984) }\end{array}$ \\
\hline
\end{tabular}




\begin{tabular}{|c|c|}
\hline & - Chernobyl Nuclear Meltdown (1986) \\
\hline 1987-1996 & $\begin{array}{l}\text { - } 1.4 \text { million applications for illegal alien amnesty (1988) } \\
\text { - The Savings and Loan Bailout (1989) } \\
\text { - The Gulf War: Kuwait Iraq (1990-1991) } \\
\text { - The Cold War ends (1991) } \\
\text { - Germany reunification announced (1991) } \\
\text { - The North American Free Trade Agreement (NAFTA) goes into effect } \\
\text { (1994) }\end{array}$ \\
\hline $1997-2006$ & $\begin{array}{l}\text { - The first major mobilization of the anti-globalization movement occurs } \\
\text { in Seattle (1999) } \\
\text { - Internet bubble booms and busts (1997-2000) } \\
\text { - Word Trade Center is destroyed by terrorists (2001) } \\
\text { - Afghanistan War begins (2001) } \\
\text { - Iraq War begins (2003) }\end{array}$ \\
\hline $2007-2016$ & - Great Recession begins (2008) \\
\hline
\end{tabular}


Stress and Well-Being 50

Table linking political, economic, technological, and societal developments to research published in $J A P$

\begin{tabular}{|c|c|c|}
\hline $\begin{array}{l}\text { Political, economic, } \\
\text { technological, and societal } \\
\text { developments }\end{array}$ & $\begin{array}{l}\text { Research topics, with an } \\
\text { emphasize on research } \\
\text { published in } J A P\end{array}$ & $\begin{array}{l}\text { Example papers } \\
\text { published in } J A P\end{array}$ \\
\hline Great Depression & - not much attention in JAP - & \\
\hline World Wars I and II & - rather little attention in JAP & \\
\hline Mass production & $\begin{array}{l}\text { Noise } \\
\text { Accidents }\end{array}$ & $\begin{array}{l}\text { Jerison (1959) } \\
\text { Davids \& Mahoney, } \\
1957\end{array}$ \\
\hline Increase in service industry & $\begin{array}{l}\text { Emotional labor } \\
\text { Service climate }\end{array}$ & $\begin{array}{l}\text { Diefendorf \& Richard, } \\
2003 \\
\text { Schneider et al., } 1998\end{array}$ \\
\hline Globalization & $\begin{array}{l}\text { Downsizing } \\
\text { Global mobility }\end{array}$ & $\begin{array}{l}\text { Brockner et al., } 1988 \\
\text { Caliguiri et al., } 1998 \\
\end{array}$ \\
\hline ICT technology & $\begin{array}{l}\text { Electronic Performance } \\
\text { Monitoring } \\
\text { Telework }\end{array}$ & $\begin{array}{l}\text { Aiello \& Kolb, } 1995 \\
\text { Gajendran et al., } 2007\end{array}$ \\
\hline Economic uncertainty & Unemployment & Caplan et al., 1989 \\
\hline Women in the workforce & $\begin{array}{l}\text { Gender differences } \\
\text { Work-family interface }\end{array}$ & $\begin{array}{l}\text { Parkes, } 1990 \\
\text { Duxbury \& Higgins, } \\
1991\end{array}$ \\
\hline Quality of work life & $\begin{array}{l}\text { Job design } \\
\text { Stress management } \\
\text { interventions }\end{array}$ & $\begin{array}{l}\text { Wall et al., } 1990 \\
\text { Van Dierendonck et al., } \\
1998\end{array}$ \\
\hline
\end{tabular}

$<$ papers already cited in our manuscript are not included in the reference list $>$

Aiello, J. R., \& Kolb, K. J. (1995). Electronic performance monitoring and social context: Impact on productivity and stress. Journal of Applied Psychology, 80, 339-353. doi: 10.1037/0021-9010.80.3.339

Brockner, J., Grover, S. L., \& Blonder, M. D. (1988). Preditors of survivors' job involvement following lyoffs: A field study. Journal of Applied Psychology, 73, 436-442. doi: 10.1037/0021-9010.73.3.436

Caligiuri, P. M., Hyland, A. M., Joshi, A., \& Bross, A. S. (1998). Testing a theoretical model for examining the relationship between family adjustment and expatriates' work adjustment. Journal of Applied Psychology, 83, 598-614. doi: 10.1037/0021-9010.83.4.598

Diefendorff, J. M., \& Richard, E. M. (2003). Antecedents and consequences of emotional display rule perceptions. Journal of Applied Psychology, 88, 284-294. doi: 10.1037/00219010.88.2.284

Duxbury, L. E., \& Higgins, C. A. (1991). Gender differences in work-family conflict. Journal of Applied Psychology, 76, 60-74. doi: 10.1037/0021-9010.76.1.60

Gajendran, R. S., \& Harrison, D. A. (2007). The good, the bad, and the unknown about 
telecommuting: Meta-analysis of psychological mediators and individual consequences. Journal of Applied Psychology, 92, 1524-1541. doi: 10.1037/0021-9010.92.6.1524

Schneider, B., White, S. S., \& Paul, M. C. (1998). Linking service climate and customer perceptions of service quality: Test of a causal model. Journal of Applied Psychology, 83, 150-163. doi: 10.1037/0021-9010.83.2.150

Van Dierendonck, D., Schaufeli, W. B., \& Buunk, B. P. (1998). The evaluation of an individual burnout intervention program: The role of inequity and social support. Journal of Applied Psychology, 83, 392-407. doi: 10.1037/0021-9010.83.3.392

Wall, T. D., Corbett, M., Martin, R., Clegg, C. W., \& Jackson, P. R. (1990). Advanced manufacturing technology, work design, and performance: A change study. Journal of Applied Psychology, 75, 691-697. doi: 10.1037/0021-9010.75.6.691 


\section{Online Appendix B}

25 Significant Publications in the 1917-1966 Era as Defined by Citation Rates (Highest to Lowest as Indexed by Google Scholar)

\begin{tabular}{|c|c|}
\hline $\begin{array}{l}\text { Murray, D. C., \& Deabler, H. } \\
\text { L. (1957). Colors and mood- } \\
\text { tones. Journal of Applied } \\
\text { Psychology, 41(5), 279-283. } \\
\text { doi:10.1037/h0041425 }\end{array}$ & $\begin{array}{l}\text { Neuropsychiatric patients, nursing assistants, and students } \\
\text { were presented with eight stimulus colors and a list of eleven } \\
\text { moods and asked to pick a color to go with each of the moods. } \\
\text { For nine mood-tones, significant differences (were found); } \\
\text { socioeconomic differences appeared to be more important } \\
\text { than either mental health or geographical (differences). } \\
\text { Certain colors were found to have about the same affective } \\
\text { meaning for all groups. In other instances there were sharp } \\
\text { group differences in the extent to which they associated a } \\
\text { given color with a certain mood-tone." (PsycINFO Database } \\
\text { Record (c) } 2013 \text { APA, all rights reserved) }\end{array}$ \\
\hline $\begin{array}{l}\text { Jerison, H. J. (1959). Effects } \\
\text { of noise on human } \\
\text { performance. Journal of } \\
\text { Applied Psychology, 43(2), } \\
\text { 96-101. } \\
\text { doi: } 10.1037 / \text { h0042914 }\end{array}$ & $\begin{array}{l}\text { Three experiments relating performance changes to noise } \\
\text { levels are reported. Noise levels used were about } 80 \mathrm{db} \\
\text { representing 'quiet' and } 110 \mathrm{db} \text { representing 'noise.' Ss in these } \\
3 \text { experiments were paid volunteer male undergraduates. In } \\
\text { Experiment I, } 9 \text { Ss were exposed to successive half hours of } \\
\text { experimental and control sessions to check Broadbent's } \\
\text { previously reported results that performance on a prolonged } \\
\text { vigilance task was poorer in noise than in quiet. In } \\
\text { Experiment II, } 14 \text { Ss were exposed to successive periods of } \\
\text { experimental and control sessions as a result of a suggestion } \\
\text { by Miles that Ss working in high energy noise fields could not } \\
\text { keep an accurate count on how far they had gone in a } \\
\text { repetitive task. In Experiment III, } 14 \text { Ss were exposed to } \\
\text { successive periods of experimental and control sessions to } \\
\text { compare judgments in quiet and in noise. It is clear that noise } \\
\text { produces readily measurable changes in human performance. } \\
\text { The effects of psychological stress may have been more } \\
\text { important than noise in determining the results. } 16 \text { refs. } \\
\text { (PsycINFO Database Record (c) } 2013 \text { APA, all rights } \\
\text { reserved) }\end{array}$ \\
\hline $\begin{array}{l}\text { McKinley, J. C., \& } \\
\text { Hathaway, S. R. (1942). A } \\
\text { Multiphasic Personality } \\
\text { Schedule (Minnesota): IV. } \\
\text { Psychasthenia. Journal of } \\
\text { Applied Psychology, 26(5), } \\
\text { 614-624. }\end{array}$ & $\begin{array}{l}\text { The derivation of a scale is reported for measuring } \\
\text { psychasthenia, a condition involving compulsions, obsessions, } \\
\text { phobias, vacillation, and excessive worry. } 504 \text { scale items } \\
\text { were applied to large groups of normal adults and college } \\
\text { students and to } 20 \text { psychiatric patients selected as cases of } \\
\text { psychasthenia. The scale selected was further refined on the } \\
\text { basis of correlation of items with total score for } 100 \text { normal }\end{array}$ \\
\hline
\end{tabular}




\begin{tabular}{|c|c|}
\hline doi:10.1037/h0063530 & $\begin{array}{l}\text { adults and } 100 \text { psychiatric cases. The final scale, composed of } \\
48 \text { items, differentiates well between normal adults and the } \\
\text { criterion group of } 20 \text { psychasthenic cases and also between } \\
\text { normal adults and } 50 \text { psychiatric cases with symptoms of } \\
\text { obsessions or compulsions. For normal adults there are small } \\
\text { differences in scores between age groups and slightly larger } \\
\text { differences between the sexes. Test-retest reliability is .79; } \\
\text { split half reliability is } .91-.94 \text {. The scale correlated .06 and .28 } \\
\text { with the authors' test for hypochondriasis for } 100 \text { normal } \\
\text { persons and } 100 \text { miscellaneous psychiatric cases, respectively, } \\
\text { and } .44 \text { and } .69 \text { with their test for depression for the same } \\
\text { groups. The scale with its scoring key is included in the } \\
\text { article. (PsycINFO Database Record (c) } 2013 \text { APA, all rights } \\
\text { reserved) }\end{array}$ \\
\hline $\begin{array}{l}\text { Kugelmass, S., \& Lieblich, I. } \\
\text { (1966). Effects of realistic } \\
\text { stress and procedural } \\
\text { interference in experimental } \\
\text { lie detection. Journal of } \\
\text { Applied Psychology, 50(3), } \\
211-216 . \\
\text { doi:10.1037/h0023324 }\end{array}$ & $\begin{array}{l}2 \text { different samples of police trainees were used to investigate: } \\
\text { (1) the effect of realistic stress in experimental lie detection, } \\
\text { and (2) the possible interference with the GSR channel } \\
\text { resulting from the simultaneous recording of blood pressure. } \\
\text { It was found that: (1) GSR detection results under stress were } \\
\text { essentially similar to those obtained in mild experimental } \\
\text { situations, and far superior in detection efficiency to analysis } \\
\text { of heart rate changes. (2) The introduction of a blood-pressure } \\
\text { cuff inflated to } 80 \text { mm. of mercury for the } 90 \text { sec. of } \\
\text { interrogation (similar to actual field measurement conditions) } \\
\text { reduced the efficiency of detection of the GSR channel. (3) } \\
\text { There is some suggestion that GSR reactivity may be related } \\
\text { to ethnic origin. (PsycINFO Database Record (c) } 2013 \text { APA, } \\
\text { all rights reserved) }\end{array}$ \\
\hline $\begin{array}{l}\text { Hauty, G. T., \& Payne, R. B. } \\
\text { (1956). Fatigue and the } \\
\text { perceptual field of work. } \\
\text { Journal of Applied } \\
\text { Psychology, 40(1), 40-46. } \\
\text { doi: } 10.1037 / \text { h0042544 }\end{array}$ & $\begin{array}{l}\text { Proficiencies in the control of several simulated aircraft } \\
\text { instruments were appraised throughout } 7 \mathrm{hr} \text {. of work to } \\
\text { determine if the control of marginally located instruments } \\
\text { suffered greater progressive impairment than did the control } \\
\text { of those instruments located centrally on the instrument panel. } \\
\text { Progressive decrement in proficiency occurred for all } \\
\text { instruments, but the rates of decline were not found to be } \\
\text { significantly different. It is concluded that in a similar work } \\
\text { situation, dissociative changes in a field of visual displays is } \\
\text { not likely to occur as a function of sustained and prolonged } \\
\text { attendance to this field of work. (PsycINFO Database Record } \\
\text { (c) } 2013 \text { APA, all rights reserved) }\end{array}$ \\
\hline $\begin{array}{l}\text { Pearson, R. G. (1957). Scale } \\
\text { analysis of a fatigue checklist. } \\
\text { Journal of Applied } \\
\text { Psychology, 41(3), 186-191. } \\
\text { doi:10.1037/h0045095 }\end{array}$ & $\begin{array}{l}\text { Two 13-item equivalent-form fatigue check-lists were } \\
\text { developed by the scale discrimination method. The items, } \\
\text { individually and collected were demonstrated to have validity } \\
\text { by comparison of the scores of experimental subjects tested } \\
\text { during and after a } 41 / 2 \text {-hour period on a pursuit task, with the } \\
\text { scores of controls who were not required to perform any task. }\end{array}$ \\
\hline
\end{tabular}




\begin{tabular}{|c|c|}
\hline & $\begin{array}{l}\text { Checklist reliabilities were of the order of .90 and both sets of } \\
\text { items met the criteria of unidimensionality of a Guttman scale } \\
\text { analysis. (PsycINFO Database Record (c) } 2013 \text { APA, all } \\
\text { rights reserved) }\end{array}$ \\
\hline $\begin{array}{l}\text { File, Q. W. (1945). The } \\
\text { measurement of supervisory } \\
\text { quality in industry. Journal of } \\
\text { Applied Psychology, 29(5), } \\
\text { 323-337. } \\
\text { doi:10.1037/h0057397 }\end{array}$ & $\begin{array}{l}\text { Final selection of } 140 \text { items from three sources provided two } \\
\text { forms of a discriminating test entitled How Supervise (see 20: } \\
\text { 282). From the various applications the author draws the } \\
\text { following conclusions: supervisory ability can be measured; } \\
\text { mental hygiene should be given prime consideration in } \\
\text { supervisor-worker relations; the outcome of supervisory } \\
\text { training programs can be evaluated by testing; individuals can } \\
\text { be more accurately selected for promotion, and the work of } \\
\text { supervisory personnel can be checked by use of this test. } \\
\text { (PsycINFO Database Record (c) } 2013 \text { APA, all rights } \\
\text { reserved) }\end{array}$ \\
\hline $\begin{array}{l}\text { Landis, C., \& Katz, S. E. } \\
\text { (1934). The validity of certain } \\
\text { questions which purport to } \\
\text { measure neurotic tendencies. } \\
\text { Journal of Applied } \\
\text { Psychology, 18(3), 343-356. } \\
\text { doi:10.1037/h0075770 }\end{array}$ & $\begin{array}{l}\text { A study was made of the B1-N neurotic tendency scale } \\
\text { (Bernreuter Personality Inventory) with the following groups } \\
\text { of patients at the New York Psychiatric Institute: manic- } \\
\text { depressive (manic), manic-depressive (depressed), dementia } \\
\text { praecox, psychoneurosis, and "others" (general paralysis, } \\
\text { psychopathic personality, etc.). The test does not clearly } \\
\text { determine neurotic tendency in individual psychiatric patients. } \\
\text { A comparison of case history items with answers on the } \\
\text { neurotic tendency scale shows a 73\% mean agreement. The } \\
\text { greatest source of disagreement seems to be in contradiction } \\
\text { between case history and patient's opinion on the } \\
\text { questionnaire. A study of the most diagnostic items shows } \\
\text { that "Yes" answers tend to have a high agreement with } \\
\text { outside validating criteria. The method of internal consistency } \\
\text { applied to this scale with normal and psychotic cases shows a } \\
\text { similar distribution of scores for both groups. A high score on } \\
\text { the neurotic scale is indicative of maladjustment, but a low } \\
\text { score does not necessarily signify emotional stability. } \\
\text { (PsycINFO Database Record (c) } 2013 \text { APA, all rights } \\
\text { reserved) }\end{array}$ \\
\hline $\begin{array}{l}\text { Rosen, E. (1951). Differences } \\
\text { between volunteers and non- } \\
\text { volunteers for psychological } \\
\text { studies. Journal of Applied } \\
\text { Psychology, 35(3), 185-193. } \\
\text { doi:10.1037/h0061411 }\end{array}$ & $\begin{array}{l}\text { In two separate situations, volunteers were compared with } \\
\text { non-volunteers on a number of psychometric and face-sheet } \\
\text { variables. In terms of the specific instruments used, it was } \\
\text { found that volunteers showed a greater tendency than non- } \\
\text { volunteers to admission of discouragements, inadequacies, } \\
\text { and anxieties, and, at the same time, some tendency toward } \\
\text { defensiveness. Volunteers were less fascist-minded than non- } \\
\text { volunteers, more intraceptive and psychological-minded, and } \\
\text { less conventional. Male volunteers tended toward greater } \\
\text { femininity of interests; female volunteers showed a higher } \\
\text { degree of serious-mindedness than non-volunteers. }\end{array}$ \\
\hline
\end{tabular}




\begin{tabular}{|c|c|}
\hline & $\begin{array}{l}\text { (PsycINFO Database Record (c) } 2013 \text { APA, all rights } \\
\text { reserved) }\end{array}$ \\
\hline $\begin{array}{l}\text { Davids, A., \& Mahoney, J. T. } \\
\text { (1957). Personality dynamics } \\
\text { and accident proneness in an } \\
\text { industrial setting. Journal of } \\
\text { Applied Psychology, 41(5), } \\
\text { 303-306. } \\
\text { doi:10.1037/h0047608 }\end{array}$ & $\begin{array}{l}\text { "Two groups of Ss... [17 men with a total of } 47 \text { accidents } \\
\text { over } 2 \text { years, and } 17 \text { accident-free men] were [compared] by } \\
\text { means of a sentence completion test... . the high accident Ss, } \\
\text { in comparison with the non-accident Ss, were significantly } \\
\text { lower on the socially desirable personality dispositions of } \\
\text { optimism, trust, and sociocentricity. In general, there were no } \\
\text { statistically significant differences... on several negative } \\
\text { personality dispositions, but there was a slight indication of } \\
\text { positive association between high accident proneness and } \\
\text { high scores on a cluster composed of the socially undesirable } \\
\text { personality dispositions of egocentricity, anxiety, and } \\
\text { resentment. There was highly significant association between } \\
\text { high accident proneness and projective responses indicative of } \\
\text { a negative attitude toward employment." (PsycINFO Database } \\
\text { Record (c) } 2013 \text { APA, all rights reserved) }\end{array}$ \\
\hline $\begin{array}{l}\text { Brayfield, A. H., \& Marsh, } \\
\text { M. M. (1957). Aptitudes, } \\
\text { interests, and personality } \\
\text { characteristics of farmers. } \\
\text { Journal of Applied } \\
\text { Psychology, 41(2), 98-103. } \\
\text { doi:10.1037/h0043236 }\end{array}$ & $\begin{array}{l}\text { A group of } 50 \text { farmers were administered the DAT, the Kuder } \\
\text { Preference Record, and the MMPI, and scores were related to } \\
\text { two criterion measures-the Brayfield-Rothe job satisfaction } \\
\text { index and instructor's rankings of on-the-job performance. } \\
\text { Their personality test pattern was within the normal range, job } \\
\text { satisfaction and job performance were unrelated, but } \\
\text { distinctive aptitude and interest test profiles emerged. } \\
\text { "Numerical ability and scientific interest were found to be } \\
\text { positively and significantly related to performance on the job. } \\
\text { Literary interest was negatively but significantly related to job } \\
\text { satisfaction. The Depression and Social Introversion- } \\
\text { Extroversion scales on the MMPI were negatively but } \\
\text { significantly correlated with job satisfaction." } 16 \text { references. } \\
\text { (PsycINFO Database Record (c) } 2013 \text { APA, all rights } \\
\text { reserved) }\end{array}$ \\
\hline $\begin{array}{l}\text { Fish, E. H. (1917). Human } \\
\text { engineering. Journal of } \\
\text { Applied Psychology, 1(2), } \\
\text { 161-174. } \\
\text { doi:10.1037/h0072801 }\end{array}$ & $\begin{array}{l}\text { Discusses the importance of development and efficiency of } \\
\text { human resources. Stability in employment results from proper } \\
\text { selection of workers. The essentials of reduced turnover of } \\
\text { employees were found to be good working conditions. The } \\
\text { employer's concerns were the employees' knowledge, his } \\
\text { initiative, loyalty, courtesy and sobriety. It was also important } \\
\text { for the employer to know about the employee's attitudes } \\
\text { towards improvement and his ambition. Once placed on the } \\
\text { job, the employee must be appraised, either by asking his } \\
\text { foreman or colleagues. Attempts have been made by } \\
\text { employers to improve safety, provide insurance, } \\
\text { transportation, housing, food, time off to relax during fatigue } \\
\text { periods, and opportunities for training and specialization, for } \\
\text { the employees. To reduce turnover, every plant must give its }\end{array}$ \\
\hline
\end{tabular}




\begin{tabular}{|c|c|}
\hline & $\begin{array}{l}\text { employees opportunity for advancement and self } \\
\text { development. (PsycINFO Database Record (c) } 2013 \text { APA, all } \\
\text { rights reserved) }\end{array}$ \\
\hline $\begin{array}{l}\text { Jones, F. E. (1964). Predictor } \\
\text { variables for creativity in } \\
\text { industrial science. Journal of } \\
\text { Applied Psychology, } 48(2) \text {, } \\
\text { 134-136. } \\
\text { doi:10.1037/h0047167 }\end{array}$ & $\begin{array}{l}25 \text { managers rated the creative performance of a } \\
\text { representative sample }(\mathrm{N}=88) \text { of industrial scientists and } \\
\text { technologists within a large company. The ratings provided a } \\
\text { continuous distribution of creativity scores. Performances on } \\
53 \text { different test variables were correlated with the criterion } \\
\text { scores to produce } 9 \text { valid predictors of the rated criterion. The } \\
\text { best multiple correlation obtainable upon the smallest number } \\
\text { of the test predictors with rated creativity is .67, corrected for } \\
\text { bias. A limited cross-validation upon a different sample } \\
\text { confirmed the validation. According to test results, the } \\
\text { typically more creative industrial scientist or engineer was } \\
\text { found to be: highly capable of reasoning well with words and } \\
\text { other symbols, fluent in the output of ideas, original in the } \\
\text { quality of ideas, emotionally stable, determined to master his } \\
\text { working environment, adventurous in outlook, high in degree } \\
\text { of scientific curiosity, and low in indication of general } \\
\text { anxiety. (PsycINFO Database Record (c) } 2013 \text { APA, all rights } \\
\text { reserved) }\end{array}$ \\
\hline $\begin{array}{l}\text { Laird, D. A. (1933). The } \\
\text { influence of noise on } \\
\text { production and fatigue, as } \\
\text { related to pitch, sensation } \\
\text { level, and steadiness of the } \\
\text { noise. Journal of Applied } \\
\text { Psychology, 17(3), 320-330. } \\
\text { doi:10.1037/h0072423 }\end{array}$ & $\begin{array}{l}\text { "Four healthy young men" worked on a dotting machine } \\
\text { under varying noise conditions regulated through an } \\
\text { audiometer. Varying complex noise reduces production. A } \\
\text { complex but steady noise decreases production more than a } \\
\text { relatively pure tone. Observations of the subject under more } \\
\text { intense noises showed muscular stiffness in the neck and legs } \\
\text { and a "great increase" in the volume of urine excreted. } \\
\text { (PsycINFO Database Record (c) } 2013 \text { APA, all rights } \\
\text { reserved) }\end{array}$ \\
\hline $\begin{array}{l}\text { Garvey, W. D., \& Taylor, F. } \\
\text { V. (1959). Interactions among } \\
\text { operator variables, system } \\
\text { dynamics, and task-induced } \\
\text { stress. Journal of Applied } \\
\text { Psychology, 43(2), 79-85. } \\
\text { doi:10.1037/h0048891 }\end{array}$ & $\begin{array}{l}\text { The relative efficiency of several machines is studied under } \\
\text { conditions of operator stress. "Forty-eight naval enlisted men } \\
\text { served as Ss in the three experiments-16 Ss per experiment." } \\
\text { In each of the } 3 \text { experiments, the Ss were divided into } 2 \\
\text { groups of 8: an experimental and a control group. } 3 \text { systems } \\
\text { were employed: acceleration control, acceleration aided } \\
\text { control, and position control. In Experiment I, one group used } \\
\text { the acceleration; the other used the acceleration aided. In } \\
\text { Experiment II, one group used the acceleration and the other } \\
\text { the acceleration aided. In Experiment III, one group used } \\
\text { position control and the other the acceleration. Stress was } \\
\text { introduced in all cases as the trials progressed. "The better } \\
\text { systems retained their advantage under stress... Thus, within } \\
\text { the confines of the present studies the "engineering" variable } \\
\text { of system dynamics proved to be ascendent over the } \\
\text { "psychological" variables of selection and training in }\end{array}$ \\
\hline
\end{tabular}




\begin{tabular}{|c|c|}
\hline & $\begin{array}{l}\text { determining relative performance under stress." (PsycINFO } \\
\text { Database Record (c) } 2013 \text { APA, all rights reserved) }\end{array}$ \\
\hline $\begin{array}{l}\text { Garth, T. R. (1920). Racial } \\
\text { Differences in Mental } \\
\text { Fatigue. Journal of Applied } \\
\text { Psychology, 4(2-3), 235-244. } \\
\text { doi:10.1037/h0072496 }\end{array}$ & $\begin{array}{l}\text { Tests reported in the Archives of Psychology No. } 41 \text { are given } \\
\text { also to Indians and negroes. The difference between whites, } \\
\text { Indians and negroes of equal educational opportunity in the } \\
\text { matter of mental fatigue shows the Indians excel the whites } \\
\text { and negroes in the curve representing fatigue in attempts and } \\
\text { accurate performance; the whites excel the negroes. From } \\
\text { Psych Bulletin 18:01:00028. (PsycINFO Database Record (c) } \\
2013 \text { APA, all rights reserved) }\end{array}$ \\
\hline $\begin{array}{l}\text { Guilford, J. S. (1952). } \\
\text { Temperament traits of } \\
\text { executives and supervisors } \\
\text { measured by the Guilford } \\
\text { Personality Inventories. } \\
\text { Journal of Applied } \\
\text { Psychology, 36(4), } 228-233 \text {. } \\
\text { doi: } 10.1037 / \text { h0060572 }\end{array}$ & $\begin{array}{l}\text { On the basis of the investigation of } 208 \text { executives and } 143 \\
\text { supervisors in a large chain grocery with regard to } \\
\text { temperament traits as revealed by scores on the Guilford } \\
\text { Personality Inventories, it was found that the executives } \\
\text { averaged significantly more sociable, free from depression, } \\
\text { emotionally stable, happy-go-lucky, active, ascendant, self- } \\
\text { confident, calm, objective, agreeable, and cooperative than } \\
\text { did the supervisors. On the basis of a criterion of success } \\
\text { defined as "job performance" ratings, the following traits } \\
\text { contributed significantly to success of the executive: } \\
\text { sociability, lack of inferiority feelings, cooperativeness, and } \\
\text { masculinity. The traits contributing significantly to the } \\
\text { success of the supervisor were: emotional stability, calmness } \\
\text { and composure, and cooperativeness. (PsycINFO Database } \\
\text { Record (c) } 2013 \text { APA, all rights reserved) }\end{array}$ \\
\hline $\begin{array}{l}\text { Howe, E. S. (1960). } \\
\text { Quantitative motivational } \\
\text { differences between } \\
\text { volunteers and nonvolunteers } \\
\text { for a psychological } \\
\text { experiment. Journal of } \\
\text { Applied Psychology, 44(2), } \\
115-120 . \\
\text { doi:10.1037/h0045002 }\end{array}$ & $\begin{array}{l}\text { How do volunteers compare with paid Ss in research? What } \\
\text { part does anxiety play in volunteering? "Two classes each of } \\
89 \text { students were given the short form of the Taylor MAS (the } \\
\text { SMAS), the Christie and Budnitzky Short Forced-Choice } \\
\text { Anxiety Scale (the SFCAS), and a 20-item scale purporting to } \\
\text { assess Murray's n Harmavoidance." } 2 \text { weeks later the Ss were } \\
\text { invited to participate as paid Ss in an "experiment." Need for } \\
\text { cash and fear of the electric shock were assessed. Volunteers } \\
\text { needed cash more, feared the shock and harm less. "As in } \\
\text { other reported studies of this kind, the SMAS did not at all } \\
\text { discriminate volunteer from other Ss; nor in fact did the } \\
\text { SFCAS." (PsycINFO Database Record (c) } 2013 \text { APA, all } \\
\text { rights reserved) }\end{array}$ \\
\hline $\begin{array}{l}\text { Bass, B. M. (1962). Mood } \\
\text { changes during training } \\
\text { laboratory. Journal of Applied } \\
\text { Psychology, 46(5), 361-364. } \\
\text { doi:10.1037/h0043752 }\end{array}$ & $\begin{array}{l}30 \text { trainees completed a mood adjective check list at } 5 \text { periods } \\
\text { during a 10-day sensitivity training laboratory for } \\
\text { management. Results indicated that differences and } \\
\text { predictable shifts in mood do occur. Specifically, skepticism } \\
\text { and anxiety decreased as most trainers would expect; other } \\
\text { moods, like depression and aggression, showed the effects of } \\
\text { particular laboratory procedures. The results also provided } \\
\text { independent evidence of the validity of the factored Nowlis }\end{array}$ \\
\hline
\end{tabular}




\begin{tabular}{|c|c|}
\hline & $\begin{array}{l}\text { and Green check list of mood adjectives. Findings generally } \\
\text { were consistent with trainer beliefs about mood changes in } \\
\text { trainees and conformed to expectations about the effects on } \\
\text { mood of defeat or victory in intergroup competition. } \\
\text { (PsycINFO Database Record (c) } 2013 \text { APA, all rights } \\
\text { reserved) }\end{array}$ \\
\hline $\begin{array}{l}\text { Elwood, R. H. (1927). The } \\
\text { role of personality traits in } \\
\text { selecting a career: the nurse } \\
\text { and the college girl. Journal } \\
\text { of Applied Psychology, 11(3), } \\
\text { 199-201. } \\
\text { doi:10.1037/h0070914 }\end{array}$ & $\begin{array}{l}\text { A group of student nurses was given a standard intelligence } \\
\text { test and the Colgate Mental Hygiene Tests-Schedule C } 2 \text { for } \\
\text { introversion-extroversion, and Schedule B } 2 \text { for } \\
\text { psychoneurotic traits. These scores were compared with those } \\
\text { of girls in colleges of liberal arts. It was found that the nurses } \\
\text { revealed far fewer signs of unhealthy emotional outlets than } \\
\text { the college girls, being more stable than } 77 \% \text { of the arts } \\
\text { students, and that the average nurse of the group tested was } \\
\text { more extrovert than } 94 \% \text { of all women entering colleges. } \\
\text { (PsycINFO Database Record (c) } 2013 \text { APA, all rights } \\
\text { reserved) }\end{array}$ \\
\hline $\begin{array}{l}\text { Hoitsma, R. (1925). The } \\
\text { reliability and relationships of } \\
\text { the Colgate mental hygiene } \\
\text { test. Journal of Applied } \\
\text { Psychology, } 9(3), 293-303 \text {. } \\
\text { doi: } 10.1037 / \text { h0075343 }\end{array}$ & $\begin{array}{l}\text { [NO ABSTRACT]. } \\
\text { Reports results from a psychometric analysis of SCHEDULE } \\
\text { Bl (PSYCHONEUROID) scale of the Colgate mental hygiene } \\
\text { test. }\end{array}$ \\
\hline $\begin{array}{l}\text { Miner, J. B., \& Culver, J. E. } \\
\text { (1955). Some aspects of the } \\
\text { executive personality. Journal } \\
\text { of Applied Psychology, 39(5), } \\
\text { 348-353. } \\
\text { doi: } 10.1037 / \text { h0045488 }\end{array}$ & $\begin{array}{l}\text { The responses of } 44 \text { top-level executives to the Tomkins-Horn } \\
\text { Picture Arrangement Test were compared with the responses } \\
\text { of } 41 \text { college professors and with those of a group of } 25 \text { males } \\
\text { comparable to the executives in age, education, and } \\
\text { intelligence level. Two characteristics were associated with } \\
\text { executives' responses (as distinguished from the responses of } \\
\text { the control groups): a generalized fear of illness and a } \\
\text { tendency to react to problem situations with a feeling of some } \\
\text { degree of helplessness and a sense of being dependent on } \\
\text { others for a solution. (PsycINFO Database Record (c) } 2013 \\
\text { APA, all rights reserved) }\end{array}$ \\
\hline $\begin{array}{l}\text { Hueting, J. E., \& Sarphati, H. } \\
\text { R. (1966). Measuring fatigue. } \\
\text { Journal of Applied } \\
\text { Psychology, 50(6), 535-538. } \\
\text { doi:10.1037/h0023984 }\end{array}$ & $\begin{array}{l}8 \text { ss } 19-23 \text { yr. Old performed an exercise during } 11 \text { min. On a } \\
\text { bicycle ergometer on } 13 \text { days in succession. Not being aware } \\
\text { of the systematic daily variations in the slope of the work } \\
\text { load, all ss showed significant correlations between subjective } \\
\text { feelings of general physical fatigue-as expressed on different } \\
\text { kinds of rating scales-and slope of work load. Regression } \\
\text { equations satisfactorily describe linear relationships between } \\
\text { load and fatigue. Factor analysis suggests a factor "increasing } \\
\text { fatigue," and a factor "decreasing fitness." (PsycINFO } \\
\text { Database Record (c) } 2013 \text { APA, all rights reserved) }\end{array}$ \\
\hline $\begin{array}{l}\text { Renner, K. E., Maher, B. A., } \\
\text { \& Campbell, D. T. (1962). }\end{array}$ & $\begin{array}{l}\text { A scoring-by-example manual was developed for use with the } \\
\text { Rotter Incomplete Sentence Blank for scoring } 3 \text { variables. }\end{array}$ \\
\hline
\end{tabular}




\begin{tabular}{|l|l|}
\hline $\begin{array}{l}\text { The validity of a method for } \\
\text { scoring sentence- completion } \\
\text { responses for anxiety, } \\
\text { dependency, and hostility. }\end{array}$ & $\begin{array}{l}\text { The aim was to provide an objective scoring technique for the } \\
\text { variables and to examine validity and discriminant scorer } \\
\text { reliability by means of a multitrait-multimethod matrix. } \\
\text { Validity data were obtained from a college population, the } \\
\text { Psychology, 46(4), 285-290. } \\
\text { doi:10.1037/h0042841 } \\
\text { criterion being peer reputation measures of the variables. Self- } \\
\text { descriptions provided a minimum competitive standard } \\
\text { against which to judge the value of sentence-completion } \\
\text { scoring. Discriminant scorer reliability was demonstrated and } \\
\text { internal consistency reliability examined. The validity } \\
\text { coefficients were modest but promising and provide a } \\
\text { background against which future multitrait-multimethod } \\
\text { examinations of other tests and keys can be evaluated. } \\
\text { (PsycINFO Database Record (c) 2013 APA, all rights }\end{array}$ \\
$\begin{array}{l}\text { reserved) } \\
\text { Knight, F. B., \& Remmers, H. }\end{array}$ \\
$\begin{array}{l}\text { The drift toward effective attention habits is significantly } \\
\text { parallel by drift in curricula toward vocational content. } \\
\text { Mental Production When }\end{array}$ \\
$\begin{array}{l}\text { Conscious motivation causes large fluctuations in mental } \\
\text { Vroduction. An experiment was conducted on a group of ten } \\
\text { Pariable. Journal of Applied } \\
\text { freshmen during probation week when they were being } \\
\text { doi:10.1037/h0075075 }\end{array}$ & $\begin{array}{l}\text { initiated into a fraternity. The control group was composed of } \\
\text { fifty-four juniors. The conclusions drawn are: The difference } \\
\text { between a genuine motivation such as the freshmen had and } \\
\text { the kind of motivation a college class contains is a difference } \\
\text { which not only offsets extreme fatigue, but further offsets } \\
\text { freshmen versus junior ability, and in addition produces twice } \\
\text { as much work per unit of time with equal accuracy. From } \\
\text { Psych Bulletin 21:07:00717. (PsycINFO Database Record (c) } \\
\text { 2013 APA, all rights reserved) }\end{array}$ \\
\hline
\end{tabular}




\section{Online Appendix C}

25 Significant Publications in the 1967-1996 Era as Defined by Citation Rates (Highest to Lowest as Indexed by Google Scholar)

\begin{tabular}{l}
\hline Eisenberger, R., Huntington, \\
R., Hutchison, S., \& Sowa, \\
D. (1986). Perceived \\
organizational support. \\
Journal of Applied \\
Psychology, 71(3), 500-507. \\
doi:10.1037/0021- \\
9010.71.3.500
\end{tabular}

9010.71 .3 .500
Administered a survey of perceived organizational support (SPOS) to 361 employees (among them postal clerks, financial trust company employees, and manufacturing firm workers) and 71 private high school teachers in 2 studies. Teachers also completed an exchange-ideology questionnaire that measured their belief that work effort should depend on treatment by the organization. Results show that (a) employees in an organization form global beliefs concerning the extent to which the organization values their contributions and cares about their well-being, (b) such perceived organizational support reduces absenteeism, and (c) the relation between perceived organizational support and absenteeism is greater for employees with a strong exchange ideology than those with a weak ideology. These findings support the social exchange view that employees' commitment to the organization is strongly influenced by their perception of the organization's commitment to them. Perceived organizational support is assumed to increase the employee's affective attachment to the organization and his/her expectancy that greater effort toward meeting organizational goals will be rewarded. It is concluded that the extent to which these factors increase work effort depends on the strength of the employee's exchange ideology favoring the trade of work effort for material and symbolic benefits. (38 ref) (PsycINFO Database Record (c) 2013 APA, all rights reserved)

Lee, R. T., \& Ashforth, B. E. (1996). A meta-analytic examination of the correlates of the three dimensions of job burnout. Journal of Applied Psychology, 81(2), 123-133. doi:10.1037/00219010.81.2.123
This meta-analysis examined how demand and resource correlates and behavioral and attitudinal correlates were related to each of the 3 dimensions of job burnout. Both the demand and resource correlates were more strongly related to emotional exhaustion than to either depersonalization or personal accomplishment. Consistent with the conservation of resources theory of stress, emotional exhaustion was more strongly related to the demand correlates than to the resource correlates, suggesting that workers might have been sensitive to the possibility of resource loss. The 3 burnout dimensions were differentially related to turnover intentions, organizational commitment, and control coping. Implications for research and the amelioration of burnout are discussed. (PsycINFO Database Record (c) 2013 APA, all rights reserved) (journal abstract) 


\begin{tabular}{|l|}
\hline Thomas, L. T., \& Ganster, \\
D. C. (1995). Impact of \\
family-supportive work \\
variables on work-family \\
conflict and strain: A control \\
perspective. Journal of \\
Applied Psychology, 80(1), \\
6-15. doi:10.1037/0021- \\
9010.80.1.6
\end{tabular}

Schneider, B., \& Bowen, D. E. (1985). Employee and customer perceptions of service in banks: Replication and extension. Journal of Applied Psychology, 70(3), 423-433. doi:10.1037/00219010.70 .3 .423
The authors examined the direct and indirect effects of organizational policies and practices that are supportive of family responsibilities on work-family conflict and psychological, physical, and behavioral measures of strain. Survey data were gathered at 45 acute-care facilities from 398 health professionals who had children aged 16 years or younger at home. Supportive practices, especially flexible scheduling and supportive supervisors, had direct positive effects on employee perceptions of control over work and family matters. Control perceptions, in turn, were associated with lower levels of work-family conflict, job dissatisfaction, depression, somatic complaints, and blood cholesterol. These results suggest that organizations can take steps that can increase employees' control over family responsibilities and that this control might help employees better manage conflicting demands of work and family life. (PsycINFO Database Record (c) 2013 APA, all rights reserved)

Replicated the 1st author and J. J. Parkington's (1979) research on the relationships between employees and customers in service organizations by analyzing survey data from 142 employees and 968 customers from 28 branches of a bank. Moderate support was found for the 1 st author and Parkington's work on correlates of stress for boundary role employees. Support was also found for relationships between branch employees' and branch customers' service perceptions and attitudes as reported by the present 1st author et al (1980). Significant relationships were reported between branch employees' perceptions of organizational human resources practices and branch customers' attitudes about service. Employee attitudes and customer attitudes were related to their own and one another's turnover intentions. Results are discussed from the perspective of promoting an integration of consumer and organizational behavior in the service sector. (51 ref) (PsycINFO Database Record (c) 2013 APA, all rights reserved)

Ostroff, C. (1992). The relationship between satisfaction, attitudes, and performance: An organizational level analysis. Journal of Applied Psychology, 77(6), 963-974. doi:10.1037/00219010.77 .6 .963
Previous research has consistently shown little relationship between job satisfaction, job attitudes, and performance for individuals, but little work has investigated these relationships at the organizational level of analysis. This study investigated the relationship between employee satisfaction, other jobrelated attitudes (commitment, adjustment, and psychological stress), and organizational performance. Organizational satisfaction and attitude data were collected from 13,808 teachers within these schools. Correlation and regression analyses supported the expected relationships between performance data were collected for 298 schools; employee 


\begin{tabular}{|c|c|}
\hline & $\begin{array}{l}\text { employee satisfaction/attitudes and organizational } \\
\text { performance. Implications of these findings are discussed. } \\
\text { (PsycINFO Database Record (c) } 2013 \text { APA, all rights } \\
\text { reserved) }\end{array}$ \\
\hline $\begin{array}{l}\text { Brown, S. P., \& Leigh, T. W. } \\
\text { (1996). A new look at } \\
\text { psychological climate and its } \\
\text { relationship to job } \\
\text { involvement, effort, and } \\
\text { performance. Journal of } \\
\text { Applied Psychology, 81(4), } \\
\text { 358-368. doi:10.1037/0021- } \\
9010.81 .4 .358\end{array}$ & $\begin{array}{l}\text { This study investigated the process by which employee } \\
\text { perceptions of the organizational environment are related to } \\
\text { job involvement, effort, and performance. The researchers } \\
\text { developed an operational definition of psychological climate } \\
\text { that was based on how employees perceive aspects of the } \\
\text { organizational environment and interpret them in relation to } \\
\text { their own well-being. Perceived psychological climate was } \\
\text { then related to job involvement, effort, and performance in a } \\
\text { path-analytic framework. Results showed that perceptions of a } \\
\text { motivating and involving psychological climate were related to } \\
\text { job involvement, which in turn was related to effort. Effort was } \\
\text { also related to work performance. Results revealed that a } \\
\text { modest but statistically significant effect of job involvement on } \\
\text { performance became nonsignificant when effort was inserted } \\
\text { into the model, indicating the mediating effect of effort on the } \\
\text { relationship. The results cross-validated well across } 2 \text { samples } \\
\text { of outside salespeople, indicating that relationships are } \\
\text { generalizable across these different sales contexts. (PsycINFO } \\
\text { Database Record (c) } 2013 \text { APA, all rights reserved) }\end{array}$ \\
\hline $\begin{array}{l}\text { Jackson, S. E., Schwab, R. } \\
\text { L., \& Schuler, R. S. (1986). } \\
\text { Toward an understanding of } \\
\text { the burnout phenomenon. } \\
\text { Journal of Applied } \\
\text { Psychology, 71(4), 630-640. } \\
\text { doi:10.1037/0021- } \\
9010.71 .4 .630\end{array}$ & $\begin{array}{l}\text { Tested } 9 \text { hypotheses about the burnout phenomenon, defined } \\
\text { as a } 3 \text {-component syndrome of emotional exhaustion, } \\
\text { depersonalization, and feelings of low personal } \\
\text { accomplishment. Burnout was hypothesized to be associated } \\
\text { with unmet employee expectations and job conditions. } \\
\text { Hypothesized consequences of burnout included (a) preferred } \\
\text { job type, (b) subsequent thoughts about leaving, (c) job-search } \\
\text { behaviors, (d) training received, (e) intentions to leave, and (f) } \\
\text { voluntary leaving. Elementary and secondary school teachers } \\
\text { (median age } 36 \text { yrs) responded to } 2 \text { questionnaires mailed to } \\
\text { their homes; } 1 \text { yr elapsed between completion of the } 2 \\
\text { questionnaires. Regression analyses of time-lagged data (N = } \\
248 \text { ) supported many of the hypothesized correlates of } \\
\text { employee burnout. It is suggested that improved } \\
\text { conceptualizations about the burnout phenomenon are needed. } \\
\text { (40 ref) (PsycINFO Database Record (c) } 2013 \text { APA, all rights } \\
\text { reserved) }\end{array}$ \\
\hline $\begin{array}{l}\text { Wright, P. (1974). The } \\
\text { harassed decision maker: } \\
\text { Time pressures, distractions, } \\
\text { and the use of evidence. } \\
\text { Journal of Applied } \\
\text { Psychology, 59(5), 555-561. }\end{array}$ & $\begin{array}{l}\text { Investigated dominant simplifying strategies people use in } \\
\text { adapting to different information processing environments. It } \\
\text { was hypothesized that judges operating under either time } \\
\text { pressure or distraction would systematically place greater } \\
\text { weight on negative evidence than would their counterparts } \\
\text { under less strainful conditions. } 6 \text { groups of male }\end{array}$ \\
\hline
\end{tabular}




\begin{tabular}{|c|c|}
\hline doi:10.1037/h0037186 & $\begin{array}{l}\text { undergraduates }(\mathrm{N}=210) \text { were presented } 5 \text { pieces of } \\
\text { information to assimilate in evaluating cars as purchase } \\
\text { options. } 3 \text { groups operated under varying time pressure } \\
\text { conditions, while } 3 \text { groups operated under varying levels of } \\
\text { distraction. Data usage models assuming disproportionately } \\
\text { heavy weighting of negative evidence provided best fits to a } \\
\text { significantly higher number of Ss in the high time pressure and } \\
\text { moderate distraction conditions. Ss attended to fewer data } \\
\text { dimensions in these conditions. (PsycINFO Database Record } \\
\text { (c) } 2013 \text { APA, all rights reserved) }\end{array}$ \\
\hline $\begin{array}{l}\text { Brief, A. P., Burke, M. J., } \\
\text { George, J. M., Robinson, B. } \\
\text { S., \& Webster, J. (1988). } \\
\text { Should negative affectivity } \\
\text { remain an unmeasured } \\
\text { variable in the study of job } \\
\text { stress?. Journal of Applied } \\
\text { Psychology, 73(2), 193-198. } \\
\text { doi:10.1037/0021- } \\
\text { 9010.73.2.193 }\end{array}$ & $\begin{array}{l}\text { We predicted that the dispositional construct negative } \\
\text { affectivity (NA) would be related to self-report measures of } \\
\text { job stress and job strain and that observed relationships } \\
\text { between these stress and strain measures would be inflated } \\
\text { considerably by NA. Results of a study of } 497 \text { managers and } \\
\text { professionals were largely consistent with those expectations. } \\
\text { Thus, we discuss implications for NA as both a } \\
\text { methodological nuisance and a substantive cause of stressful } \\
\text { work events, and conclude that NA should no longer remain an } \\
\text { unmeasured variable in the study of job stress. (PsycINFO } \\
\text { Database Record (c) } 2013 \text { APA, all rights reserved) }\end{array}$ \\
\hline $\begin{array}{l}\text { Rusbult, C. E., \& Farrell, D. } \\
\text { (1983). A longitudinal test of } \\
\text { the investment model: The } \\
\text { impact on job satisfaction, } \\
\text { job commitment, and } \\
\text { turnover of variations in } \\
\text { rewards, costs, alternatives, } \\
\text { and investments. Journal of } \\
\text { Applied Psychology, } 68(3) \text {, } \\
\text { 429-438. doi:10.1037/0021- } \\
\text { 9010.68.3.429 }\end{array}$ & $\begin{array}{l}\text { A 12-mo longitudinal study of } 88 \text { newly hired nurses and } \\
\text { junior accountants (mean age of all Ss } 24 \text { yrs) tested a series of } \\
\text { assumptions from the authors' (see record 1981-31481-001) } \\
\text { investment model concerning the determinants of job } \\
\text { satisfaction, job commitment, and turnover. In general, greater } \\
\text { job satisfaction resulted from high job rewards and low job } \\
\text { costs; whereas strong job commitment was produced by high } \\
\text { rewards, low costs, poor alternative quality, and large } \\
\text { investment size. Whereas the impact of job rewards on } \\
\text { satisfaction and commitment remained relatively constant, job } \\
\text { costs seemed to exert an increasingly powerful influence over } \\
\text { time. Investment size also exerted greater impact on job } \\
\text { commitment with the passage of time. Just prior to their } \\
\text { leaving, the job commitment of Ss who left was best predicted } \\
\text { by a combination of rewards, costs, and alternatives. Ss who } \\
\text { stayed and those who left differed from one another with } \\
\text { regard to changes over time in each investment model factor- } \\
\text { those who left experienced greater decline in rewards, increase } \\
\text { in costs, increase in alternative quality, and decrease in } \\
\text { investment size than those who stayed. Turnover appeared to } \\
\text { be mediated by a decline over time in degree of job } \\
\text { commitment. ( } 28 \text { ref) (PsycINFO Database Record (c) } 2013 \\
\text { APA, all rights reserved) }\end{array}$ \\
\hline $\begin{array}{l}\text { Motowidlo, S. J., Packard, J. } \\
\text { S., \& Manning, M. R. }\end{array}$ & $\begin{array}{l}\text { Examined occupational stress and its relation with individual } \\
\text { characteristics, job conditions, stressful events, affect, and job }\end{array}$ \\
\hline
\end{tabular}


(1986). Occupational stress: Its causes and consequences for job performance. Journal of Applied Psychology, 71(4), 618-629. doi: $10.1037 / 0021-$ 9010.71.4.618 performance. Study 1, in which 104 nurses participated in group discussions and 96 nurses (mean age 36 yrs) completed a questionnaire, identified 45 stressful events (appended) for nurses. In Study 2, 171 nurses (mean age 34.6 yrs) completed another questionnaire and were rated by a supervisor and/or a coworker. Findings show that ratings of interpersonal aspects of job performance (i.e., sensitivity, warmth, consideration, tolerance) and cognitive/motivational aspects (i.e., concentration, composure, perseverance, adaptability) correlated significantly with self-reported perceptions of stressful events, subjective stress, depression, and hostility. Models developed through path analysis suggest that the frequency and subjective intensity of the 45 events identified in Study 1 caused feelings of stress, leading to depression and causing decrements in interpersonal and cognitive/motivational aspects of job performance. (43 ref) (PsycINFO Database Record (c) 2013 APA, all rights reserved)
Beehr, T. A., Walsh, J. T., \& Taber, T. D. (1976).

Relationships of stress to individually and organizationally valued states: Higher order needs as a moderator. Journal of Applied Psychology, 61(1), 41-47. doi:10.1037/00219010.61 .1 .41

Data from 79 male and 64 female members of a white-collar union employed in drafting, mechanical, and technical-clerical jobs in a midwestern manufacturing company show that some effects of role stresses on individually valued states were incompatible with their effects on 3 organizationally valued motivational states: involvement, effort toward quantity, and effort toward quality. Specifically, role overload was correlated positively with organizationally valued outcomes, but also with 3 adverse individual outcomes: job dissatisfaction, fatigue, and tension. Two other role stresses, role ambiguity and nonparticipation, had adverse effects on both individually and organizationally valued psychological states. Relationships between role stresses and individually valued outcomes were moderated by higher order need strength. (21 ref) (PsycINFO Database Record (c) 2013 APA, all rights reserved)

James, L. A., \& James, L. R. (1989). Integrating work environment perceptions: Explorations into the measurement of meaning. Journal of Applied Psychology, 74(5), 739-751. doi: $10.1037 / 0021-$ 9010.74.5.739 wherein each assessment of meaning reflects a general
Many of the perceptual variables used in

industrial/organizational psychology assess the meaning that work environment attributes have for individuals (e.g., the ambiguity of role prescriptions). This study represents an initial attempt to test the hypothesis that a unifying theme exists for integrating diverse measures of meaning. The unifying theme is based on a hierarchical cognitive model appraisal of the degree to which the overall work environment is personally beneficial versus personally detrimental to the organizational well-being of the individual. Results of conformitory factor analyses on multiple samples supported a hierarchical cognitive model with a single, general factor 


\begin{tabular}{|c|c|}
\hline & $\begin{array}{l}\text { underlying measures of meaning. These results are used to } \\
\text { explain the substantive impact of work environment } \\
\text { perceptions on individual outcomes. (PsycINFO Database } \\
\text { Record (c) } 2013 \text { APA, all rights reserved) }\end{array}$ \\
\hline $\begin{array}{l}\text { Ganster, D. C., Fusilier, M. } \\
\text { R., \& Mayes, B. T. (1986). } \\
\text { Role of social support in the } \\
\text { experience of stress at work. } \\
\text { Journal of Applied } \\
\text { Psychology, } 71(1), 102-110 . \\
\text { doi:10.1037/0021- } \\
9010.71 .1 .102\end{array}$ & $\begin{array}{l}\text { It has been hypothesized that the positive relation between } \\
\text { stress and strain responses is stronger for individuals who have } \\
\text { low levels of social support than for those who have high } \\
\text { levels of support. This hypothesis that social support buffers } \\
\text { the negative effects of stress has been tested extensively in a } \\
\text { variety of settings, with highly conflicting results. Some } \\
\text { theorists have recently proposed that the moderating effect of } \\
\text { social support is itself buffered by other variables such as sex } \\
\text { or social class. The present study examined the role of social } \\
\text { support in the experience of work stress with a sample large } \\
\text { enough to provide statistically powerful tests of models of } \\
\text { social support that specify } 2-\text { and } 3 \text {-way interactions. Data } \\
\text { were obtained from } 326 \text { employees (mean age } 32.5 \text { yrs). No } \\
\text { support for higher order interactive models was found. In } \\
\text { addition, no evidence emerged demonstrating any buffering } \\
\text { effect for social support. Arguments are advanced for a } \\
\text { parsimonious model in which social support has a modest } \\
\text { direct effect of lowering experienced strain. ( } 34 \text { ref) } \\
\text { (PsycINFO Database Record (c) } 2013 \text { APA, all rights } \\
\text { reserved) }\end{array}$ \\
\hline $\begin{array}{l}\text { Russell, D. W., Altmaier, E., } \\
\text { \& Van Velzen, D. (1987). } \\
\text { Job-related stress, social } \\
\text { support, and burnout among } \\
\text { classroom teachers. Journal } \\
\text { of Applied Psychology, } \\
72(2), 269-274 . \\
\text { doi:10.1037/0021- } \\
9010.72 .2 .269\end{array}$ & $\begin{array}{l}\text { In this study we examined the effects of job-related stressful } \\
\text { events and social support on burnout among teachers. We } \\
\text { conducted a mail survey of a random sample of public school } \\
\text { teachers in Iowa. Consistent with findings in previous } \\
\text { research, teacher characteristics such as age, sex, and grade } \\
\text { level taught were predictive of burnout. We also found that the } \\
\text { number of stressful events experienced and social support were } \\
\text { predictive of teacher burnout. Some evidence of the stress- } \\
\text { moderating role of social support was also found. Teachers } \\
\text { who reported that they had supportive supervisors and } \\
\text { indicated that they received positive feedback concerning their } \\
\text { skills and abilities from others were less vulnerable to burnout. } \\
\text { We discuss the implications of these findings for programs } \\
\text { aimed at preventing teacher burnout. (PsycINFO Database } \\
\text { Record (c) } 2013 \text { APA, all rights reserved) }\end{array}$ \\
\hline $\begin{array}{l}\text { Anderson, C. R. (1977). } \\
\text { Locus of control, coping } \\
\text { behaviors, and performance } \\
\text { in a stress setting: A } \\
\text { longitudinal study. Journal of } \\
\text { Applied Psychology, 62(4), } \\
\text { 446-451. doi:10.1037/0021- }\end{array}$ & $\begin{array}{l}\text { Examined the relationship between managerial locus of control } \\
\text { (Rotter's Internal-External Control Scale), perceived stress } \\
\text { (Subjective Stress Scale), coping behaviors (task- vs emotion- } \\
\text { centered as defined in the R. L. Kahn et al } 1964 \text { typology), and } \\
\text { performance (credit ratings). } 90 \text { small business owner- } \\
\text { managers participated in } 2 \text { data collection phases over a } 2^{1 / 2-y r} \\
\text { interval following the effects of a major disaster. Internals }\end{array}$ \\
\hline
\end{tabular}




\begin{tabular}{|c|c|}
\hline 9010.62 .4 .446 & $\begin{array}{l}\text { were found to perceive less stress, employ more task-centered } \\
\text { coping behaviors, and employ fewer emotion-centered coping } \\
\text { behaviors than externals. Successful internals became more } \\
\text { internal, whereas unsuccessful externals became more external } \\
\text { over the } 2 \frac{1}{2}-\mathrm{yr} \text { interval. Changes in performance were related } \\
\text { to changes in locus of control. The nature of locus of control as } \\
\text { a possible cause of task behavior and as an effect of } \\
\text { environmental experience is examined. ( } 15 \text { ref) (PsycINFO } \\
\text { Database Record (c) } 2013 \text { APA, all rights reserved) }\end{array}$ \\
\hline $\begin{array}{l}\text { Jackson, S. E. (1983). } \\
\text { Participation in decision } \\
\text { making as a strategy for } \\
\text { reducing job-related strain. } \\
\text { Journal of Applied } \\
\text { Psychology, 68(1), 3-19. } \\
\text { doi:10.1037/0021- } \\
9010.68 .1 .3\end{array}$ & $\begin{array}{l}\text { Proposed a causal model that describes the effect of } \\
\text { participation in decision making on perceived influence, role } \\
\text { conflict, role ambiguity, personal and job-related } \\
\text { communications, social support, emotional strain, overall job } \\
\text { satisfaction, absenteeism, and turnover intention. The model } \\
\text { was tested using a Solomon 4-group design and modified to } \\
\text { include } 2 \text { posttests; it was conducted in a hospital outpatient } \\
\text { facility with } 95 \text { nursing and clerical employees who were } \\
\text { randomly assigned to an increased-participation or a control } \\
\text { condition and to a pretest or no-pretest condition. Outcomes } \\
\text { were assessed after } 3 \text { and } 6 \text { mo. Analysis provided support for } \\
\text { a somewhat revised model. After } 6 \text { mo, participation was } \\
\text { shown to have a significant, negative effect on role conflict } \\
\text { and role ambiguity and a positive effect on perceived } \\
\text { influence. Role conflict and ambiguity were, in turn, positively } \\
\text { related to emotional strain and negatively related to job } \\
\text { satisfaction. Emotional strain was positively related to absence } \\
\text { frequency and turnover intention. Perceived influence was } \\
\text { positively related to job satisfaction and positively related to } \\
\text { turnover intention. Participation in decision making appeared } \\
\text { to be an important causal determinant of role strains, which } \\
\text { were, in turn, important precursors of both individual and } \\
\text { organizational outcomes. (46 ref) (PsycINFO Database Record } \\
\text { (c) } 2013 \text { APA, all rights reserved) }\end{array}$ \\
\hline $\begin{array}{l}\text { Etzion, D. (1984). } \\
\text { Moderating effect of social } \\
\text { support on the stress- } \\
\text { burnout relationship. Journal } \\
\text { of Applied Psychology, } \\
69(4), 615-622 \text {. } \\
\text { doi:10.1037/0021- } \\
9010.69 .4 .615\end{array}$ & $\begin{array}{l}\text { Assessed the extent of life and work stresses, the availability of } \\
\text { social support, and experience of burnout through a self-report } \\
\text { questionnaire administered to } 357 \text { female (mean age } 32 \text { yrs) } \\
\text { and } 273 \text { male (mean age } 39 \text { yrs) Israeli managers and human } \\
\text { service professionals. Analysis showed that female Ss } \\
\text { experienced more burnout and stress in life than did male Ss; } \\
\text { no difference was found between the sexes for stress in work. } \\
\text { Burnout was positively correlated with stress and negatively } \\
\text { correlated with social support in both life and work. Further } \\
\text { analysis revealed different patterns of moderating effects of } \\
\text { social support on the relationship between stress and burnout } \\
\text { for males and females: The relationship between work stress } \\
\text { and burnout was moderated by support in life for females and }\end{array}$ \\
\hline
\end{tabular}




\begin{tabular}{|c|c|}
\hline & $\begin{array}{l}\text { by support in work for males. It is concluded that special } \\
\text { attention should be paid to cultural, occupational, and sex } \\
\text { differences in social support research and the exploration of its } \\
\text { buffering effect. ( } 47 \text { ref) (PsycINFO Database Record (c) } 2013 \\
\text { APA, all rights reserved) }\end{array}$ \\
\hline $\begin{array}{l}\text { Spector, P. E., Dwyer, D. J., } \\
\text { \& Jex, S. M. (1988). } \\
\text { Relation of job stressors to } \\
\text { affective, health, and } \\
\text { performance outcomes: A } \\
\text { comparison of multiple data } \\
\text { sources. Journal of Applied } \\
\text { Psychology, 73(1), 11-19. } \\
\text { doi:10.1037/0021- } \\
9010.73 .1 .11\end{array}$ & $\begin{array}{l}\text { It is widely accepted that job conditions are a causal factor in } \\
\text { stress outcomes for employees. This conclusion, however, is } \\
\text { based almost entirely on single data source, self-report studies, } \\
\text { which demonstrate correlations between environmental } \\
\text { perceptions and stress outcomes. This study collected stressor } \\
\text { data from two sources, the job incumbent and her supervisor. } \\
\text { Convergent and discriminant validities were found for four } \\
\text { stressors (autonomy, workload, number of hours worked, and } \\
\text { number of people worked for) but not for three others (role } \\
\text { ambiguity, constraints, and interpersonal conflict). } \\
\text { Correlations were found between perception of stressors and } \\
\text { outcomes, the latter including both affective and symptoms. } \\
\text { Smaller correlations were found between supervisor reports of } \\
\text { stressors and outcomes, the latter including both affective and } \\
\text { symptoms. Alternative causal models relevant to these results } \\
\text { are discussed. The need for causal research including } \\
\text { experimental designs, longitudinal designs, and multiple data } \\
\text { sources are also discussed. (PsycINFO Database Record (c) } \\
2013 \text { APA, all rights reserved) }\end{array}$ \\
\hline $\begin{array}{l}\text { Latack, J. C. (1986). Coping } \\
\text { with job stress: Measures } \\
\text { and future directions for } \\
\text { scale development. Journal } \\
\text { of Applied Psychology, } \\
71(3), 377-385 . \\
\text { doi:10.1037/0021- } \\
9010.71 .3 .377\end{array}$ & $\begin{array}{l}\text { Presents construct validity evidence for } 3 \text { measures of coping } \\
\text { behavior related to job stress: control, escape, and symptom } \\
\text { management. The questionnaires were completed by } 109 \\
\text { managers and professionals in a manufacturing firm or an } \\
\text { osteopathic hospital. The psychometric properties of the scales } \\
\text { as well as preliminary evidence for construct validity support } \\
\text { their further use and evaluation. Measurement issues are } \\
\text { identified, particularly by the time-dependent nature of coping } \\
\text { and the dilemma of multimethod assessment. Suggestions are } \\
\text { offered for future coping scale development. ( } 49 \text { ref) } \\
\text { (PsycINFO Database Record (c) } 2013 \text { APA, all rights } \\
\text { reserved) }\end{array}$ \\
\hline $\begin{array}{l}\text { Burke, M. J., Brief, A. P., \& } \\
\text { George, J. M. (1993). The } \\
\text { role of negative affectivity in } \\
\text { understanding relations } \\
\text { between self-reports of } \\
\text { stressors and strains: A } \\
\text { comment on the applied } \\
\text { psychology literature. } \\
\text { Journal of Applied } \\
\text { Psychology, } 78(3), 402-412 \text {. }\end{array}$ & $\begin{array}{l}\text { On the basis of a brief review of the health, organizational, and } \\
\text { personality psychology literatures supportive of the } \\
\text { expectation that observed relations between self-reports of } \\
\text { stressors and strains are influenced by the mood-dispositional } \\
\text { dimension negative affectivity (NA), reanalyses of } 4 \text { data sets } \\
\text { were conducted. Results of these reanalyses, contrary to the } \\
\text { assertions of several authors in the applied psychology } \\
\text { literature, offered further support for the hypothesized } \\
\text { "nuisance" properties of NA in studies involving relations } \\
\text { between self-reports of stressors and strain. A discussion of }\end{array}$ \\
\hline
\end{tabular}


doi: $10.1037 / 0021-$

9010.78.3.402 how NA and other mood-dispositional dimensions may be of interest to investigators concerned with relations between selfreports of any condition of employment and any affective state of workers is presented. (PsycINFO Database Record (c) 2013 APA, all rights reserved)

Caplan, R. D., \& Jones, K. W. (1975). Effects of work load, role ambiguity, and Type A personality on anxiety, depression, and heart rate. Journal of Applied Psychology, 60(6), 713-719. doi: $10.1037 / 0021-$ 9010.60.6.713

Studied Type A personality (hard driving, persistent, involved in work) as a conditioner of the effects of quantitative work load and role ambiguity (stresses) on anxiety, depression, age, $23 \mathrm{yrs}$ ) of a university computer system that was approaching a 23-day shutdown. Each respondent was his own control. Stress, personality, and psychological strain were assessed by questionnaire, and heart rate was measured. Change scores were then analyzed. Role ambiguity was resentment, and heart rate (strains) among 73 male users (mean positively associated with anxiety, depression, and resentment; subjective work load was positively associated only with anxiety. Anxiety was positively related to heart rate. The relationship between work load and anxiety was greatest for Type A persons, and a similar but nonsignificant trend appeared for the effects of anxiety on heart rate. Response and respondent specificity are discussed. (20 ref) (PsycINFO Database Record (c) 2013 APA, all rights reserved)

Yuille, J. C., \& Cutshall, J. L. (1986). A case study of eyewitness memory of a crime. Journal of Applied Psychology, 71(2), 291-301. doi: $10.1037 / 0021$ 9010.71 .2 .291

21 witnesses observed a shooting incident in which 1 person was killed and a 2 nd seriously wounded. The incident took place on a major thoroughfare in midafternoon. All of the witnesses were interviewed by the investigating police, and 13 witnesses (aged 15-32 yrs) agreed to a research interview 4-5 mo after the event. In the present study, the eyewitness accounts provided in both the police and research interviews were analyzed. The witnesses were highly accurate in their accounts, and there was little change in amount or accuracy of recall over 5 mo. However, some aspects of color memory and age, height, and weight estimations were found to be erroneous. The eyewitnesses resisted leading questions, and their stress levels at the time of the event appeared to have no negative effects on subsequent memory. The results differ from the pattern of many laboratory studies of eyewitness memory (i.e., in the degree to which the witnesses in the present study were actively involved in the event) and point to the need for field research of this type to evaluate the generalizability of laboratory experiments. (41 ref) (PsycINFO Database Record (c) 2013 APA, all rights reserved)

Parkes, K. R. (1990). Coping, negative affectivity, and the work environment: Additive and interactive
The present study tested the hypothesis that direct coping would moderate relations between work stress and mental health outcome, whereas suppression (a form of emotionfocused coping) would show an overall effect on outcome. 


\begin{tabular}{|l|l|}
\hline $\begin{array}{l}\text { predictors of mental health. } \\
\text { Journal of Applied } \\
\text { Psychology, 75(4),399-409. } \\
\text { doi:10.1037/0021- }\end{array}$ & $\begin{array}{l}\text { Data on coping, perceived work demand and support, and } \\
\text { affective symptoms were obtained from trainee teachers (N } \\
\text { 15010.75.4.399 }\end{array}$ \\
also were observed; men reported more use of suppression \\
than did women. In addition, negative affectivity (NA) was \\
examined as a confounding variable and as an index of \\
reactivity in stress-outcome relations. NA acted to inflate \\
associations between work perceptions and affective \\
symptoms, but it was also a significant moderator variable; \\
high NA subjects showed greater reactivity to work demand \\
than did low NA subjects. (PsycINFO Database Record (c) \\
2013 APA, all rights reserved)
\end{tabular}




\section{Online Appendix D}

25 Significant Publications in the 1997-Present Era as Defined by Citation Rates (Highest to Lowest as Indexed by Google Scholar)

\begin{tabular}{|c|c|}
\hline Citation & Abstract \\
\hline $\begin{array}{l}\text { Demerouti, E., Bakker, } \\
\text { A. B., Nachreiner, F., \& } \\
\text { Schaufeli, W. B. (2001). } \\
\text { The job demands- } \\
\text { resources model of } \\
\text { burnout. Journal of } \\
\text { Applied Psychology, } \\
\text { 86(3), 499-512. } \\
\text { doi:10.1037/0021- } \\
9010.86 .3 .499\end{array}$ & $\begin{array}{l}\text { The job demands-resources (JD-R) model proposes that working } \\
\text { conditions can be categorized into } 2 \text { broad categories, job } \\
\text { demands and job resources, that are differentially related to } \\
\text { specific outcomes. A series of LISREL analyses using self-reports } \\
\text { as well as observer ratings of the working conditions provided } \\
\text { strong evidence for the JD-R model: Job demands are primarily } \\
\text { related to the exhaustion component of burnout, whereas (lack of) } \\
\text { job resources are primarily related to disengagement. Highly } \\
\text { similar patterns were observed in each of } 3 \text { occupational groups: } \\
\text { human services, industry, and transport (total N = 374). In } \\
\text { addition, results confirmed the } 2 \text {-factor structure (exhaustion and } \\
\text { disengagement) of a new burnout instrument-the Oldenburg } \\
\text { Burnout Inventory-and suggested that this structure is essentially } \\
\text { invariant across occupational groups. (PsycINFO Database Record } \\
\text { (c) } 2013 \text { APA, all rights reserved) (journal abstract) }\end{array}$ \\
\hline $\begin{array}{l}\text { Rhoades, L., \& } \\
\text { Eisenberger, R. (2002). } \\
\text { Perceived organizational } \\
\text { support: A review of the } \\
\text { literature. Journal of } \\
\text { Applied Psychology, } \\
87(4), 698-714 . \\
\text { doi:10.1037/0021- } \\
9010.87 .4 .698\end{array}$ & $\begin{array}{l}\text { The authors reviewed more than } 70 \text { studies concerning employees' } \\
\text { general belief that their work organization values their } \\
\text { contribution and cares about their well-being (perceived } \\
\text { organizational support; POS). A meta-analysis indicated that } 3 \\
\text { major categories of beneficial treatment received by employees } \\
\text { (i.e., fairness, supervisor support, and organizational rewards and } \\
\text { favorable job conditions) were associated with POS. POS, in turn, } \\
\text { was related to outcomes favorable to employees (e.g., job } \\
\text { satisfaction, positive mood) and the organization (e.g., affective } \\
\text { commitment, performance, and lessened withdrawal behavior). } \\
\text { These relationships depended on processes assumed by } \\
\text { organizational support theory: employees' belief that the } \\
\text { organization's actions were discretionary, feeling of obligation to } \\
\text { aid the organization, fulfillment of socioemotional needs, and } \\
\text { performance-reward expectancies. (PsycINFO Database Record } \\
\text { (c) } 2013 \text { APA, all rights reserved) (journal abstract) }\end{array}$ \\
\hline $\begin{array}{l}\text { Maslach, C., \& Leiter, M. } \\
\text { P. (2008). Early } \\
\text { predictors of job burnout } \\
\text { and engagement. Journal } \\
\text { of Applied Psychology, } \\
\text { 93(3), 498-512. } \\
\text { doi:10.1037/0021- } \\
9010.93 .3 .498\end{array}$ & $\begin{array}{l}\text { A longitudinal study predicted changes in burnout or engagement } \\
\text { a year later by identifying } 2 \text { types of early indicators at the initial } \\
\text { assessment. Organizational employees }(\mathrm{N}=466) \text { completed } \\
\text { measures of burnout and } 6 \text { areas of worklife at } 2 \text { times with a } 1- \\
\text { year interval. Those people who showed an inconsistent pattern at } \\
\text { Time } 1 \text { were more likely to change over the year than were those } \\
\text { who did not. Among this group, those who also displayed a } \\
\text { workplace incongruity in the area of fairness moved to burnout at } \\
\text { Time 2, while those without this incongruity moved toward }\end{array}$ \\
\hline
\end{tabular}




\begin{tabular}{|c|c|}
\hline & $\begin{array}{l}\text { engagement. The implications of these } 2 \text { predictive indicators are } \\
\text { discussed in terms of the enhanced ability to customize } \\
\text { interventions for targeted groups within the workplace. } \\
\text { (PsycINFO Database Record (c) } 2013 \text { APA, all rights reserved) } \\
\text { (journal abstract) }\end{array}$ \\
\hline $\begin{array}{l}\text { Bass, B. M., Avolio, B. } \\
\text { J., Jung, D. I., \& Berson, } \\
\text { Y. (2003). Predicting unit } \\
\text { performance by assessing } \\
\text { transformational and } \\
\text { transactional leadership. } \\
\text { Journal of Applied } \\
\text { Psychology, 88(2), 207- } \\
\text { 218. doi:10.1037/0021- } \\
\text { 9010.88.2.207 }\end{array}$ & $\begin{array}{l}\text { How do leadership ratings collected from units operating under } \\
\text { stable conditions predict subsequent performance of those units } \\
\text { operating under high stress and uncertainty? To examine this } \\
\text { question, the authors calculated the predictive relationships for the } \\
\text { transformational and transactional leadership of } 72 \text { light infantry } \\
\text { rifle platoon leaders for ratings of unit potency, cohesion, and } \\
\text { performance for U.S. Army platoons participating in combat } \\
\text { simulation exercises. Both transformational and transactional } \\
\text { contingent reward leadership ratings of platoon leaders and } \\
\text { sergeants positively predicted unit performance. The relationship } \\
\text { of platoon leadership to performance was partially mediated } \\
\text { through the unit's level of potency and cohesion. Implications, } \\
\text { limitations, and future directions for leadership research are } \\
\text { discussed. (PsycINFO Database Record (c) } 2013 \text { APA, all rights } \\
\text { reserved) (journal abstract) }\end{array}$ \\
\hline $\begin{array}{l}\text { Colquitt, J. A., LePine, J. } \\
\text { A., \& Noe, R. A. (2000). } \\
\text { Toward an integrative } \\
\text { theory of training } \\
\text { motivation: A meta- } \\
\text { analytic path analysis of } \\
20 \text { years of research. } \\
\text { Journal of Applied } \\
\text { Psychology, 85(5), 678- } \\
\text { 707. doi:10.1037/0021- } \\
\text { 9010.85.5.678 }\end{array}$ & $\begin{array}{l}\text { This article meta-analytically summarizes the literature on training } \\
\text { motivation, its antecedents, and its relationships with training } \\
\text { outcomes such as declarative knowledge, skill acquisition, and } \\
\text { transfer. Significant predictors of training motivation and } \\
\text { outcomes included individual characteristics (e.g., locus of } \\
\text { control, conscientiousness, anxiety, age, cognitive ability, self- } \\
\text { efficacy, valence, job involvement) and situational characteristics } \\
\text { (e.g., climate). Moreover, training motivation explained } \\
\text { incremental variance in training outcomes beyond the effects of } \\
\text { cognitive ability. Meta-analytic path analyses further showed that } \\
\text { the effects of personality, climate, and age on training outcomes } \\
\text { were only partially mediated by self-efficacy, valence, and job } \\
\text { involvement. These findings are discussed in terms of their } \\
\text { practical significance and their implications for an integrative } \\
\text { theory of training motivation. (PsycINFO Database Record (c) } \\
2013 \text { APA, all rights reserved) (journal abstract) }\end{array}$ \\
\hline $\begin{array}{l}\text { McKee-Ryan, F., Song, } \\
\text { Z., Wanberg, C. R., \& } \\
\text { Kinicki, A. J. (2005). } \\
\text { Psychological and } \\
\text { Physical Well-Being } \\
\text { During Unemployment: } \\
\text { A Meta-Analytic Study. } \\
\text { Journal of Applied } \\
\text { Psychology, 90(1), 53- } \\
\text { 76. doi:10.1037/0021- }\end{array}$ & $\begin{array}{l}\text { The authors used theoretical models to organize the diverse } \\
\text { unemployment literature, and meta-analytic techniques were used } \\
\text { to examine the impact of unemployment on worker well-being } \\
\text { across } 104 \text { empirical studies with } 437 \text { effect sizes. Unemployed } \\
\text { individuals had lower psychological and physical well-being than } \\
\text { did their employed counterparts. Unemployment duration and } \\
\text { sample type (school leaver vs. mature unemployed) moderated the } \\
\text { relationship between mental health and unemployment, but the } \\
\text { current unemployment rate and the amount of unemployment } \\
\text { benefits did not. Within unemployed samples, work-role }\end{array}$ \\
\hline
\end{tabular}




\begin{tabular}{|c|c|}
\hline 9010.90 .1 .53 & $\begin{array}{l}\text { centrality, coping resources (personal, social, financial, and time } \\
\text { structure), cognitive appraisals, and coping strategies displayed } \\
\text { stronger relationships with mental health than did human capital } \\
\text { or demographic variables. The authors identify gaps in the } \\
\text { literature and propose directions for future unemployment } \\
\text { research. (PsycINFO Database Record (c) } 2013 \text { APA, all rights } \\
\text { reserved) (journal abstract) }\end{array}$ \\
\hline $\begin{array}{l}\text { Wright, T. A., \& } \\
\text { Cropanzano, R. (1998). } \\
\text { Emotional exhaustion as } \\
\text { a predictor of job } \\
\text { performance and } \\
\text { voluntary turnover. } \\
\text { Journal of Applied } \\
\text { Psychology, 83(3), 486- } \\
\text { 493. doi:10.1037/0021- } \\
\text { 9010.83.3.486 }\end{array}$ & $\begin{array}{l}\text { Recent research suggests that a better understanding of emotional } \\
\text { exhaustion requires the development of new theoretical } \\
\text { perspectives. To that end, with the conservation of resources } \\
\text { model (COR) as the theoretical framework, the present 1-year } \\
\text { longitudinal study was undertaken. Composed of } 52 \text { social welfare } \\
\text { workers, this research examined the relationship of emotional } \\
\text { exhaustion to job satisfaction, voluntary turnover, and job } \\
\text { performance. Positive affectivity (PA) and negative affectivity } \\
\text { (NA) were used as control variables. Whereas emotional } \\
\text { exhaustion was unrelated to job satisfaction, it was associated with } \\
\text { both performance and subsequent turnover. In addition, the } \\
\text { relationship between emotional exhaustion and performance and } \\
\text { also between emotional exhaustion and turnover remained } \\
\text { significant above and beyond the effects of PA and NA. Future } \\
\text { research directions and implications of the findings are introduced. } \\
\text { (PsycINFO Database Record (c) } 2013 \text { APA, all rights reserved) } \\
\text { (journal abstract) }\end{array}$ \\
\hline $\begin{array}{l}\text { Cropanzano, R., Rupp, } \\
\text { D. E., \& Byrne, Z. S. } \\
\text { (2003). The relationship } \\
\text { of emotional exhaustion } \\
\text { to work attitudes, job } \\
\text { performance, and } \\
\text { organizational citizenship } \\
\text { behaviors. Journal of } \\
\text { Applied Psychology, } \\
\text { 88(1), 160-169. } \\
\text { doi:10.1037/0021- } \\
9010.88 .1 .160\end{array}$ & $\begin{array}{l}\text { The authors investigated the negative consequences of emotional } \\
\text { exhaustion for individual employees and their employers. On the } \\
\text { basis of social exchange theory, the authors proposed that } \\
\text { emotional exhaustion would predict job performance, } 2 \text { classes of } \\
\text { organizational citizenship behavior, and turnover intentions. In } \\
\text { addition, the authors posited that the relationship between } \\
\text { emotional exhaustion and effective work behaviors would be } \\
\text { mediated by organizational commitment. With only a few } \\
\text { exceptions, the results of } 2 \text { field studies supported the authors' } \\
\text { expectations. In addition, emotional exhaustion exerted an } \\
\text { independent effect on these criterion variables beyond the impact } \\
\text { of age, gender, and ethnicity. (PsycINFO Database Record (c) } \\
2013 \text { APA, all rights reserved) (journal abstract) }\end{array}$ \\
\hline $\begin{array}{l}\text { Humphrey, S. E., } \\
\text { Nahrgang, J. D., \& } \\
\text { Morgeson, F. P. (2007). } \\
\text { Integrating motivational, } \\
\text { social, and contextual } \\
\text { work design features: A } \\
\text { meta-analytic summary } \\
\text { and theoretical extension } \\
\text { of the work design }\end{array}$ & $\begin{array}{l}\text { The authors developed and meta-analytically examined } \\
\text { hypotheses designed to test and extend work design theory by } \\
\text { integrating motivational, social, and work context characteristics. } \\
\text { Results from a summary of } 259 \text { studies and } 219,625 \text { participants } \\
\text { showed that } 14 \text { work characteristics explained, on average, } 43 \% \text { of } \\
\text { the variance in the } 19 \text { worker attitudes and behaviors examined. } \\
\text { For example, motivational characteristics explained } 25 \% \text { of the } \\
\text { variance in subjective performance, } 2 \% \text { in turnover perceptions, } \\
34 \% \text { in job satisfaction, } 24 \% \text { in organizational commitment, and }\end{array}$ \\
\hline
\end{tabular}




\begin{tabular}{|c|c|}
\hline $\begin{array}{l}\text { literature. Journal of } \\
\text { Applied Psychology, } \\
\text { 92(5), 1332-1356. } \\
\text { doi:10.1037/0021- } \\
9010.92 .5 .1332\end{array}$ & $\begin{array}{l}26 \% \text { in role perception outcomes. Beyond motivational } \\
\text { characteristics, social characteristics explained incremental } \\
\text { variances of } 9 \% \text { of the variance in subjective performance, } 24 \% \text { in } \\
\text { turnover intentions, } 17 \% \text { in job satisfaction, } 40 \% \text { in organizational } \\
\text { commitment, and } 18 \% \text { in role perception outcomes. Finally, } \\
\text { beyond both motivational and social characteristics, work context } \\
\text { characteristics explained incremental variances of } 4 \% \text { in job } \\
\text { satisfaction and } 16 \% \text { in stress. The results of this study suggest } \\
\text { numerous opportunities for the continued development of work } \\
\text { design theory and practice. (PsycINFO Database Record (c) } 2013 \\
\text { APA, all rights reserved) (journal abstract) }\end{array}$ \\
\hline $\begin{array}{l}\text { Fitzgerald, L. F., } \\
\text { Drasgow, F., Hulin, C. } \\
\text { L., Gelfand, M. J., \& } \\
\text { Magley, V. J. (1997). } \\
\text { Antecedents and } \\
\text { consequences of sexual } \\
\text { harassment in } \\
\text { organizations: A test of } \\
\text { an integrated model. } \\
\text { Journal of Applied } \\
\text { Psychology, 82(4), 578- } \\
\text { 589. doi:10.1037/0021- } \\
\text { 9010.82.4.578 }\end{array}$ & $\begin{array}{l}\text { Sexual harassment of women in organizational settings has } \\
\text { recently become a topic of interest to researchers and the general } \\
\text { public alike. Although numerous studies document its frequency, } \\
\text { the development of conceptual models identifying antecedents and } \\
\text { consequences of harassment has proceeded at a slower pace. In } \\
\text { this article, an empirical test of a recently proposed conceptual } \\
\text { model is described. According to the model, organizational } \\
\text { climate for sexual harassment and job gender context are critical } \\
\text { antecedents of sexual harassment; harassment, in turn, influences } \\
\text { work-related variables (e.g., job satisfaction); psychological states } \\
\text { (e.g., anxiety and depression); and physical health. On the basis of } \\
\text { a sample of women employed at a large, regulated utility } \\
\text { company, the model's predictions were generally supported. } \\
\text { (PsycINFO Database Record (c) 2013 APA, all rights reserved) } \\
\text { (journal abstract) }\end{array}$ \\
\hline $\begin{array}{l}\text { Jex, S. M., \& Bliese, P. } \\
\text { D. (1999). Efficacy } \\
\text { beliefs as a moderator of } \\
\text { the impact of work- } \\
\text { related stressors: A } \\
\text { multilevel study. Journal } \\
\text { of Applied Psychology, } \\
84(3), 349-361 . \\
\text { doi:10.1037/0021- } \\
9010.84 .3 .349\end{array}$ & $\begin{array}{l}\text { This study built on previous exploratory research (S. M. Jex \& D. } \\
\text { M. Gudanowski, 1992) that examined both self-efficacy and } \\
\text { collective efficacy as moderators of stressor-strain relations. } \\
\text { Based on survey data collected from } 2,273 \text { U.S. Army soldiers } \\
\text { representing } 36 \text { companies, it was found that both self- and } \\
\text { collective efficacy moderated the relationship between stressors } \\
\text { and strains. Multilevel random coefficient model results revealed } \\
\text { that respondents with strong self-efficacy reacted less negatively } \\
\text { in terms of psychological and physical strain to long work hours } \\
\text { and work overload than did those reporting low levels of efficacy. } \\
\text { In addition, respondents with high levels of self-efficacy } \\
\text { responded more positively in terms of job satisfaction to tasks } \\
\text { with high significance than did those with low efficacy. The } \\
\text { results also revealed that group-level collective efficacy moderated } \\
\text { the relationship between work overload and job satisfaction and } \\
\text { between task significance and organizational commitment. } \\
\text { Limitations of the study and implications of these findings are } \\
\text { discussed. (PsycINFO Database Record (c) } 2013 \text { APA, all rights } \\
\text { reserved) (journal abstract) }\end{array}$ \\
\hline Frone, M. R. (2000). & This study examined the relation between work-family conflict \\
\hline
\end{tabular}




\begin{tabular}{|c|c|}
\hline $\begin{array}{l}\text { Work-family conflict } \\
\text { and employee psychiatric } \\
\text { disorders: The national } \\
\text { comorbidity survey. } \\
\text { Journal of Applied } \\
\text { Psychology, } 85(6), 888 \text { - } \\
\text { 895. doi:10.1037/0021- } \\
\text { 9010.85.6.888 }\end{array}$ & $\begin{array}{l}\text { and several types of psychiatric disorders: mood, anxiety, } \\
\text { substance dependence, and substance abuse. Survey data were } \\
\text { obtained from a representative national sample of } 2,700 \text { employed } \\
\text { adults who were either married or the parent of a child } 18 \text { years } \\
\text { old or younger. Hierarchical logistic regression analyses revealed } \\
\text { that both work-to-family and family-to-work conflict were } \\
\text { positively related to having a mood, anxiety, and substance } \\
\text { dependence disorder. Depending on the type of work-family } \\
\text { conflict and type of disorder, employees who reported } \\
\text { experiencing work-family conflict often were } 1.99-29.66 \text { times } \\
\text { more likely than were employees who reported no work-family } \\
\text { conflict to experience a clinically significant mental health } \\
\text { problem. No support was found for gender differences. } \\
\text { (PsycINFO Database Record (c) } 2013 \text { APA, all rights reserved) } \\
\text { (journal abstract) }\end{array}$ \\
\hline $\begin{array}{l}\text { Podsakoff, N. P., LePine, } \\
\text { J. A., \& LePine, M. A. } \\
\text { (2007). Differential } \\
\text { challenge stressor- } \\
\text { hindrance stressor } \\
\text { relationships with job } \\
\text { attitudes, turnover } \\
\text { intentions, turnover, and } \\
\text { withdrawal behavior: A } \\
\text { meta-analysis. Journal of } \\
\text { Applied Psychology, } \\
\text { 92(2), 438-454. } \\
\text { doi:10.1037/0021- } \\
\text { 9010.92.2.438 }\end{array}$ & $\begin{array}{l}\text { In this article, a 2-dimensional work stressor framework is used to } \\
\text { explain inconsistencies in past research with respect to stressor } \\
\text { relationships with retention-related criteria. Results of meta- } \\
\text { analyses of } 183 \text { independent samples indicated that whereas } \\
\text { hindrance stressors had dysfunctional relationships with these } \\
\text { criteria (negative relationships with job satisfaction and } \\
\text { organizational commitment and positive relationships with } \\
\text { turnover intentions, turnover, and withdrawal behavior), } \\
\text { relationships with challenge stressors were generally the opposite } \\
\text { (positive relationships with job satisfaction and organizational } \\
\text { commitment and negative relationships with turnover intentions } \\
\text { and turnover). Results also suggested that the differential } \\
\text { relationships between challenge stressors and hindrance stressors } \\
\text { and the more distal criteria (withdrawal behavior and turnover) } \\
\text { were due, in part, to the mediating effects of job attitudes. } \\
\text { (PsycINFO Database Record (c) } 2013 \text { APA, all rights reserved) } \\
\text { (journal abstract) }\end{array}$ \\
\hline $\begin{array}{l}\text { Ford, M. T., Heinen, B. } \\
\text { A., \& Langkamer, K. L. } \\
\text { (2007). Work and family } \\
\text { satisfaction and conflict: } \\
\text { A meta-analysis of cross- } \\
\text { domain relations. Journal } \\
\text { of Applied Psychology, } \\
\text { 92(1), 57-80. } \\
\text { doi:10.1037/0021- } \\
9010.92 .1 .57\end{array}$ & $\begin{array}{l}\text { This meta-analysis is a review of the literature examining the } \\
\text { relations among stressors, involvement, and support in the work } \\
\text { and family domains, work-family conflict, and satisfaction outside } \\
\text { of those domains. Results suggest that a considerable amount of } \\
\text { variability in family satisfaction is explained by work domain- } \\
\text { specific variables, whereas a considerable amount of variability in } \\
\text { job satisfaction is explained by family domain-specific variables, } \\
\text { with job and family stress having the strongest effects on work- } \\
\text { family conflict and cross-domain satisfaction. The authors propose } \\
\text { future directions for research on work and family issues focusing } \\
\text { on other explanatory mechanisms and moderators of cross-domain } \\
\text { relations. (PsycINFO Database Record (c) } 2013 \text { APA, all rights } \\
\text { reserved) (journal abstract) }\end{array}$ \\
\hline Major, V. S., Klein, K. J., & Despite public concern about time pressures experienced by \\
\hline
\end{tabular}




\begin{tabular}{|c|c|}
\hline $\begin{array}{l}\text { \& Ehrhart, M. G. (2002). } \\
\text { Work time, work } \\
\text { interference with family, } \\
\text { and psychological } \\
\text { distress. Journal of } \\
\text { Applied Psychology, } \\
\text { 87(3), 427-436. } \\
\text { doi:10.1037/0021- } \\
9010.87 .3 .427\end{array}$ & $\begin{array}{l}\text { working parents, few scholars have explicitly examined the effects } \\
\text { of work time on work-family conflict. The authors developed and } \\
\text { tested a model of the predictors of work time and the relationships } \\
\text { between time, work interference with family (WIF), and } \\
\text { psychological distress. Survey data came from } 513 \text { employees in a } \\
\text { Fortune } 500 \text { company. As predicted, several work and family } \\
\text { characteristics were significantly related to work time. In addition, } \\
\text { work time was significantly, positively related to WIF, which in } \\
\text { turn was significantly, negatively related to distress. The results } \\
\text { suggest that work time fully or partially mediates the effects of } \\
\text { many work and family characteristics on WIF. (PsycINFO } \\
\text { Database Record (c) } 2013 \text { APA, all rights reserved) (journal } \\
\text { abstract) }\end{array}$ \\
\hline $\begin{array}{l}\text { Bond, F. W., \& Bunce, } \\
\text { D. (2003). The Role of } \\
\text { Acceptance and Job } \\
\text { Control in Mental Health, } \\
\text { Job Satisfaction, and } \\
\text { Work Performance. } \\
\text { Journal of Applied } \\
\text { Psychology, 88(6), 1057- } \\
\text { 1067. doi:10.1037/0021- } \\
\text { 9010.88.6.1057 }\end{array}$ & $\begin{array}{l}\text { Acceptance, the willingness to experience thoughts, feelings, and } \\
\text { physiological sensations without having to control them or let } \\
\text { them determine one's actions, is a major individual determinant of } \\
\text { mental health and behavioral effectiveness in a more recent theory } \\
\text { of psychopathology. This 2-wave panel study examined the ability } \\
\text { of acceptance also to explain mental health, job satisfaction, and } \\
\text { performance in the work domain. The authors hypothesized that } \\
\text { acceptance would predict these } 3 \text { outcomes } 1 \text { year later in a } \\
\text { sample of customer service center workers in the United Kingdom } \\
\text { (N = 412). Results indicated that acceptance predicted mental } \\
\text { health and an objective measure of performance over and above } \\
\text { job control, negative affectivity, and locus of control. These } \\
\text { beneficial effects of having more job control were enhanced when } \\
\text { people had higher levels of acceptance. The authors discuss the } \\
\text { theoretical and practical relevance of this individual characteristic } \\
\text { to occupational health and performance. (PsycINFO Database } \\
\text { Record (c) } 2013 \text { APA, all rights reserved) (journal abstract) }\end{array}$ \\
\hline $\begin{array}{l}\text { Bowling, N. A., \& Beehr, } \\
\text { T. A. (2006). Workplace } \\
\text { harassment from the } \\
\text { victim's perspective: A } \\
\text { theoretical model and } \\
\text { meta-analysis. Journal of } \\
\text { Applied Psychology, } \\
\text { 91(5), 998-1012. } \\
\text { doi:10.1037/0021- } \\
\text { 9010.91.5.998 }\end{array}$ & $\begin{array}{l}\text { Although workplace harassment affects the lives of many } \\
\text { employees, until recently it has been relatively ignored in the } \\
\text { organizational psychology literature. First, the authors introduced } \\
\text { an attribution- and reciprocity-based model that explains the link } \\
\text { between harassment and its potential causes and consequences. } \\
\text { The authors then conducted a meta-analysis to examine the } \\
\text { potential antecedents and consequences of workplace harassment. } \\
\text { As shown by the meta-analysis, both environmental and individual } \\
\text { difference factors potentially contributed to harassment and } \\
\text { harassment was negatively related to the well-being of both } \\
\text { individual employees and their employing organizations. } \\
\text { Furthermore, harassment contributed to the variance in many } \\
\text { outcomes, even after controlling for } 2 \text { of the most commonly } \\
\text { studied occupational stressors, role ambiguity and role conflict. } \\
\text { (PsycINFO Database Record (c) } 2013 \text { APA, all rights reserved) } \\
\text { (journal abstract) }\end{array}$ \\
\hline
\end{tabular}




\begin{tabular}{|l}
\hline Cavanaugh, M. A., \\
Boswell, W. R., \\
Roehling, M. V., \& \\
Boudreau, J. W. (2000). \\
An empirical \\
examination of self- \\
reported work stress \\
among U.S. managers. \\
Journal of Applied \\
Psychology, 85(1), 65- \\
74. doi:10.1037/0021- \\
9010.85.1.65 \\
\hline
\end{tabular}

Chen, G., \& Bliese, P. D. (2002). The role of different levels of leadership in predicting self- and collective efficacy: Evidence for discontinuity. Journal of Applied Psychology, 87(3), 549-556. doi: $10.1037 / 0021-$ 9010.87.3.549
This study proposes that self-reported work stress among U.S. managers is differentially related (positively and negatively) to work outcomes depending on the stressors that are being evaluated. Specific hypotheses were derived from this general proposition and tested using a sample of 1,886 U.S. managers and longitudinal data. Regression results indicate that challengerelated self-reported stress is positively related to job satisfaction and negatively related to job search. In contrast, hindrance-related self-reported stress is negatively related to job satisfaction and positively related to job search and turnover. Future research directions are discussed. (PsycINFO Database Record (c) 2013 APA, all rights reserved) (journal abstract)

This study identified potential discontinuities in the antecedents of efficacy beliefs across levels of analysis, with a particular focus on the role of leadership climate at different organizational levels. Random coefficient modeling analyses conducted on data collected from 2,585 soldiers in 86 combat units confirmed that soldiers' experience, role clarity, and psychological strain predicted self-efficacy to a greater extent than did leadership climate. Also, leadership climate at a higher organizational level related to self-efficacy through role clarity, whereas leadership climate at a lower organizational level related to self-efficacy through psychological strain. Group-level analyses identified leadership climate at a higher organizational level as the strongest predictor of collective efficacy. Theoretical and practical implications and directions for future research are discussed. (PsycINFO Database Record (c) 2013 APA, all rights reserved) (journal abstract)

Carr, J. Z., Schmidt, A. M., Ford, J. K., \& DeShon, R. P. (2003). Climate perceptions matter: A meta-analytic path analysis relating molar climate, cognitive and affective states, and individual level work outcomes. Journal of Applied Psychology, 88(4), 605-619. doi:10.1037/00219010.88.4.605

Halbesleben, J. B. (2006). Sources of social support and burnout: A
Although workplace climate has been extensively studied, the research has not led to firm conclusions as to its relationship with individual level work outcomes. The authors used C. Ostroffs (1993) taxonomy to organize dimensions labeled as workplace climate and then used meta-analytic techniques to test a path analytic model. The model posited that climate affects individual level outcomes through its impact on underlying cognitive and affective states. An extensive literature search yielded 51 empirical studies with 70 samples. The results suggest that the 3 higher order facets of climate (affective, cognitive, and instrumental) affected individual level outcomes of job performance, psychological well-being, and withdrawal through their impact on organizational commitment and job satisfaction. (PsycINFO Database Record (c) 2013 APA, all rights reserved) (journal abstract)

The Conservation of Resources (COR) model of burnout (Hobfoll \& Freedy, 1993) suggests that resources are differentially related to burnout dimensions. In this paper, I provide a meta-analysis of 


\begin{tabular}{|c|c|}
\hline $\begin{array}{l}\text { meta-analytic test of the } \\
\text { conservation of resources } \\
\text { model. Journal of } \\
\text { Applied Psychology, } \\
\text { 91(5), 1134-1145. } \\
\text { doi:10.1037/0021- } \\
\text { 9010.91.5.1134 }\end{array}$ & $\begin{array}{l}\text { the social support and burnout literature, finding that social } \\
\text { support, as a resource, did not yield different relationships across } \\
\text { the } 3 \text { burnout dimensions (emotional exhaustion, } \\
\text { depersonalization, and personal accomplishment), challenging the } \\
\text { COR model. However, when considering the source of the social } \\
\text { support (work vs. nonwork) as a moderator, I found that work- } \\
\text { related sources of social support, because of their more direct } \\
\text { relationship to work demands, were more closely associated with } \\
\text { exhaustion than depersonalization or personal accomplishment; } \\
\text { the opposite pattern was found with nonwork sources of support. I } \\
\text { discuss the implications of this finding in relation to the COR } \\
\text { model and suggest future research directions to clarify the } \\
\text { relationship between resources and burnout dimensions. } \\
\text { (PsycINFO Database Record (c) } 2013 \text { APA, all rights reserved) } \\
\text { (journal abstract) }\end{array}$ \\
\hline $\begin{array}{l}\text { Hershcovis, M. S., } \\
\text { Turner, N., Barling, J., } \\
\text { Arnold, K. A., Dupré, K. } \\
\text { E., Inness, M., \& ... } \\
\text { Sivanathan, N. (2007). } \\
\text { Predicting workplace } \\
\text { aggression: A meta- } \\
\text { analysis. Journal of } \\
\text { Applied Psychology, } \\
\text { 92(1), 228-238. } \\
\text { doi:10.1037/0021- } \\
\text { 9010.92.1.228 }\end{array}$ & $\begin{array}{l}\text { The authors conducted a meta-analysis of } 57 \text { empirical studies (59 } \\
\text { samples) concerning enacted workplace aggression to answer } 3 \\
\text { research questions. First, what are the individual and situational } \\
\text { predictors of interpersonal and organizational aggression? Second, } \\
\text { within interpersonal aggression, are there different predictors of } \\
\text { supervisor- and coworker-targeted aggression? Third, what are the } \\
\text { relative contributions of individual (i.e., trait anger, negative } \\
\text { affectivity, and biological sex) and situational (i.e., injustice, job } \\
\text { dissatisfaction, interpersonal conflict, situational constraints, and } \\
\text { poor leadership) factors in explaining interpersonal and } \\
\text { organizational aggression? Results show that both individual and } \\
\text { situational factors predict aggression and that the pattern of } \\
\text { predictors is target specific. Implications for future research are } \\
\text { discussed. (PsycINFO Database Record (c) } 2013 \text { APA, all rights } \\
\text { reserved) (journal abstract) }\end{array}$ \\
\hline $\begin{array}{l}\text { Schneider, K. T., Swan, } \\
\text { S., \& Fitzgerald, L. F. } \\
\text { (1997). Job-related and } \\
\text { psychological effects of } \\
\text { sexual harassment in the } \\
\text { workplace: Empirical } \\
\text { evidence from two } \\
\text { organizations. Journal of } \\
\text { Applied Psychology, } \\
\text { 82(3), 401-415. } \\
\text { doi:10.1037/0021- } \\
\text { 9010.82.3.401 }\end{array}$ & $\begin{array}{l}\text { Previous evidence regarding the outcomes of sexual harassment in } \\
\text { the workplace has come mainly from self-selected samples or } \\
\text { analogue studies or those using inadequate measures. The sexual } \\
\text { harassment experiences, coping responses, and job-related and } \\
\text { psychological outcomes of } 447 \text { female private-sector employees } \\
\text { and } 300 \text { female university employees were examined. } \\
\text { Discriminant function analyses indicated that women who had not } \\
\text { been harassed and women who had experienced low, moderate, } \\
\text { and high frequencies of harassment could be distinguished on the } \\
\text { basis of both job-related and psychological outcomes. These } \\
\text { outcomes could not be attributed to negative affective disposition, } \\
\text { attitudes toward harassment, or general job stress. Results suggest } \\
\text { that relatively low-level but frequent types of sexual harassment } \\
\text { can have significant negative consequences for working women. } \\
\text { (PsycINFO Database Record (c) } 2013 \text { APA, all rights reserved) } \\
\text { (journal abstract) }\end{array}$ \\
\hline
\end{tabular}




\begin{tabular}{|c|c|}
\hline $\begin{array}{l}\text { Judge, T. A., \& Colquitt, } \\
\text { J. A. (2004). } \\
\text { Organizational Justice } \\
\text { and Stress: The } \\
\text { Mediating Role of Work- } \\
\text { Family Conflict. Journal } \\
\text { of Applied Psychology, } \\
\text { 89(3), 395-404. } \\
\text { doi:10.1037/0021- } \\
9010.89 .3 .395\end{array}$ & $\begin{array}{l}\text { This study examined the relationship between organizational } \\
\text { justice and stress and whether work-family conflict was a } \\
\text { mediator of the relationship. Distributive, procedural, } \\
\text { interpersonal, and informational injustice were cast as stressors to } \\
\text { explore their relationships with the stress levels of } 174 \text { faculty } \\
\text { members employed at } 23 \text { U.S. universities. The results revealed } \\
\text { that procedural and interpersonal justice had the strongest } \\
\text { relationships with stress, and that these effects were mediated by } \\
\text { work-family conflict. The presence of justice seemed to allow } \\
\text { participants to better manage the interface of their work and } \\
\text { family lives, which was associated with lower stress levels. These } \\
\text { results were observed even when controlling for job satisfaction } \\
\text { and the presence of organizational work-family policies. } \\
\text { (PsycINFO Database Record (c) } 2014 \text { APA, all rights reserved) } \\
\text { (journal abstract) }\end{array}$ \\
\hline $\begin{array}{l}\text { Crawford, E. R., LePine, } \\
\text { J. A., \& Rich, B. L. } \\
\text { (2010). Linking job } \\
\text { demands and resources to } \\
\text { employee engagement } \\
\text { and burnout: A } \\
\text { theoretical extension and } \\
\text { meta-analytic test. } \\
\text { Journal of Applied } \\
\text { Psychology, 95(5), 834- } \\
848 . \\
\text { doi:10.1037/a0019364 }\end{array}$ & $\begin{array}{l}\text { We refine and extend the job demands-resources model with } \\
\text { theory regarding appraisal of stressors to account for } \\
\text { inconsistencies in relationships between demands and } \\
\text { engagement, and we test the revised theory using meta-analytic } \\
\text { structural modeling. Results indicate support for the refined and } \\
\text { updated theory. First, demands and burnout were positively } \\
\text { associated, whereas resources and burnout were negatively } \\
\text { associated. Second, whereas relationships among resources and } \\
\text { engagement were consistently positive, relationships among } \\
\text { demands and engagement were highly dependent on the nature of } \\
\text { the demand. Demands that employees tend to appraise as } \\
\text { hindrances were negatively associated with engagement, and } \\
\text { demands that employees tend to appraise as challenges were } \\
\text { positively associated with engagement. Implications for future } \\
\text { research are discussed. (PsycINFO Database Record (c) } 2013 \\
\text { APA, all rights reserved) (journal abstract) }\end{array}$ \\
\hline
\end{tabular}

